Acta Protozool. (2017) 56: 191-210

www.ejournals.eu/Acta-Protozoologica

doi:10.4467/16890027AP.17.017.7498

PROTOZOOLOGICA

\title{
Response of Sphagnum Testate Amoebae to Drainage, Subsequent Re-wetting and Associated Changes in the Moss Carpet - Results from a Three Year Mesocosm Experiment
}

\author{
Isabelle KOENIG ${ }^{1}$, Florence SCHWENDENER ${ }^{1}$, Matthieu MULOT ${ }^{1,2}$, Edward A. D. MITCHELL ${ }^{1,3}$
}

${ }^{1}$ Laboratory of Soil Biodiversity, University of Neuchâtel, Neuchâtel, Switzerland; ${ }^{2}$ Station biologique, Adaptation et diversité en milieu marin, Evolution des Protistes et Ecosystèmes Pélagiques, Roscoff, France; ${ }^{3}$ Jardin Botanique de Neuchâtel, Neuchâtel, Switzerland

\begin{abstract}
Sphagnum peatlands represent a globally significant pool and sink of carbon but these functions are threatened by ongoing climate change. Testate amoebae are useful bioindicators of hydrological changes, but little experimental work has been done on the impact of water table changes on communities.

Using a mesocosm experimental setting that was previously used to assess the impact of drought disturbance on communities and ecosystem processes with three contrasted water table positions: wet $(-4 \mathrm{~cm})$, intermediate $(-15 \mathrm{~cm})$ and dry $(-25 \mathrm{~cm})$, we studied the capacity of testate amoeba communities to recover when the water table was kept at $-10 \mathrm{~cm}$ for all plots. The overall experiment lasted three years. We assessed the taxonomic and functional trait responses of testate amoeba communities. The selected traits were hypothesised to be correlated to moisture content (response traits: shell size, aperture position) or trophic role (effect traits: mixotrophy, aperture size controlling prey range).

During the disturbance phase, the mixotrophic species Hyalosphenia papilio dominated the wet and intermediate plots, while the community shifted to a dominance of "dry indicators" (Corythion dubium, Nebela tincta, Cryptodifflugia oviformis) and corresponding traits (loss of mixotrophy, and dominance of smaller taxa with ventral or ventral-central aperture) in dry plots. During the recovery phase we observed two contrasted trends in the previously wet and intermediate plots: communities remained similar where the Sphagnum carpet remained intact but species and traits indicators of drier conditions increased in plots where it had degraded. In the former dry plots, indicators and traits of wet conditions increased by the end of the experiment.

This is one of the first experiment simulating a disturbance and subsequent recovery in ex-situ mesocosms of Sphagnum peatland focusing on the response of testate amoebae community structure as well as functional traits to water table manipulation. The results generally confirmed that testate amoebae respond within a few months to hydrological changes and thus represent useful bioindicators for assessing current and past hydrological changes in Sphagnum peatlands.
\end{abstract}

Keywords: Mesocosm experiment, Testate amoebae, Functional traits, Recovery, Disturbance, Sphagnum peatlands, bio-indicators, water table depth.

Address for correspondence: Isabelle Koenig, Laboratory of Soil Biodiversity, University of Neuchâtel, Rue Emile-Argand 11, CH-2000 Neuchâtel, Switzerland; E-mail: Isabelle.koenig@unine.ch 


\section{INTRODUCTION}

The increasing influence of human activities on the biosphere makes it necessary to assess how direct and indirect impacts are affecting ecosystems (MEA 2005). Biomonitoring is an efficient approach for evaluating environmental condition in general and specifically the impact of perturbation but also ecosystem restoration and recovery (MEA 2005; Bonnett et al. 2011; Norris et al. 2011; Church et al. 2014; Bonn et al. 2016). Bioindicator taxa must be sensitive enough to rapidly response to environmental changes, and have measurable characteristics (e.g. community composition, morphology, or function) that are correlated to relevant processes (e.g. C sequestration, Niemi and McDonald 2004; Payne 2013). Protists play essential functional roles and are useful bioindicators in aquatic as well as terrestrial ecosystems (Caron et al. 2009; Norris et al. 2011; Pinto et al. 2014). Our focus here is on the use of testate amoebae living in Sphagnum peatlands as indicators of hydrological changes.

Testate amoebae are a polyphyletic group of unicellular protists which build a shell, termed a test. Although they are generally studied as a homogeneous ecological and functional group, they belong to three phylogenetic groups, each of which has specific morphological traits: 1) Arcellinida (Kosakyan et al. 2016), with "lobose" (wide) pseudopods, 2) Euglyphida (Cavalier-Smith and Chao 2003), with "filose" (narrow) pseudopods and (for most of the group) a test produced of self-secreted silica scales (idiosomes), both groups with a single pseudostome (aperture) to the test and 3) Amphitremidae (Gomaa et al. 2013), with "filose" pseudopods and two pseudostomes. Some taxa (in all three groups) possess photosynthetic endosymbionts (i.e. they are mixotrophic). Identification is based on test characteristics, thus allowing the use of this group in palaeoecological studies (Charman 2001). Tests are made of self-secreted protein, self-secreted silica plates (idiosomes) or an agglutination (xenosomes) of either prey (diatom frustules, euglyphid plates, i.e. kleptoplastidy - Lahr et al. 2015) or mineral particles present locally (Ogden and Hedley 1980; Delaine et al. 2017). Testate amoebae are a dominant group of micro-organisms in wet and humid environments (Gilbert et al. 1998; Gilbert and Mitchell 2006) and play a central role in soil microbial food webs and C cycling in Sphagnum peatlands (Wilkinson and Mitchell 2010; Jassey et al. 2015). Their community structure is correlated with key environmental gradi- ent such as humidity (generally measured as water table depth), $\mathrm{pH}$, or nutrient richness (Mitchell et al. 2008).

In addition to classical taxonomy-based approaches, changes in communities may be studied within the functional diversity framework. This approach aims at understanding the links between well selected morphological / behavioural traits and environmental constraint (Lavorel and Garnier 2002; Violle et al. 2007). The functional diversity framework was developed initially for plants, macro-invertebrates and fish and was more recently been applied to micro-eukaryotes and especially testate amoebae (Fournier et al. 2012, 2015; Arrieira et al. 2015; Kajukało et al. 2016; Marcisz et al. 2016). Selected morphological and physiological traits have been shown to be linked to hydrological gradients (Fournier et al. 2012). As functional traits are directly linked to ongoing processes, they could be used to monitor ecosystem functioning and give information on ecological niche dimensions (Mouillot et al. 2007; Holt 2009; Kearney et al. 2010).

To be useful, functional traits must be 1) related to known ecological processes and 2) measurable at the species level (Violle et al. 2007; Mlambo 2014). In practice, traits are most often selected based on correlations identified in observational ecological studies. Such correlations should ideally be further tested using controlled experiments to link traits to specific environmental changes. Mesocosm experiments provide the necessary level of control to assess how selected traits respond to manipulation, while other variables are kept (approximately) constant in the different treatments (Benton et al. 2007).

This study is the follow-up of a twenty months mesocosm experimental study in which we assessed the responses of testate amoeba communities to manipulated water levels $(-4 \mathrm{~cm},-15 \mathrm{~cm},-25 \mathrm{~cm}$, Koenig et al. 2018). At the end of the experiment, the mesocosms were kept in operation, providing the opportunity for further experimentation. We adjusted the water level to $-10 \mathrm{~cm}$ in all mesocosms to assess how the testate amoeba communities may recover post-stress and to compare the taxonomic and functional trait responses over the two phases of the overall experiment. We hypothesised that the strongest changes during the recovery experiment would be observed in the previously driest plots $(-25 \mathrm{~cm})$ as these experienced the highest contrast in both the first and second phase of the experiment. 


\section{MATERIAL AND METHODS}

\section{Experimental design}

We set up a mesocosm experiment to simulate the effect of water table changes on Sphagnum-peatlands. Mesocosms consisted of tanks filled with water (Fig. 1). In each tank a pierced PVC tube (45 $\mathrm{cm}$ high, $12 \mathrm{~cm}$ diameter) was filled with a peat core topped with a carpet of Sphagnum fallax (Mulot et al. 2015). The system allowed the manipulation of the water level independently in each mesocosm. The Sphagnum carpets were collected simultaneously on the same Sphagnum patch, in the Creux de 1'Epral peatland, Canton du Jura (4712'18.3”N; 00656'05.83”E; elevation: $990 \mathrm{~m}$ a.s.l.). At the beginning of the experiment (T0 - 02/08/2012), all plots were seeded with a water extract from pool, hummock and lawn to provide the full community potential as describe in Mulot et al. (2015). The water table was set at $-4 \mathrm{~cm}$ (wet treatment $-\mathrm{W}$ ), $-15 \mathrm{~cm}$ (intermediate treatment - I) and $-25 \mathrm{~cm}$ (dry treatment D), with five replicates of each treatment. On 27/03/2015 the water level was set at $-10 \mathrm{~cm}$ in all mesocosms (i.e. beginning of recovery phase). To assess the impact of water table changes, samples were extracted on 27/03/2014 (D1, 18 month after the beginning of the experiment), then on $18 / 05 / 2015$ (R1, two months after equalisation of water table) and on 24/09/2015 (R2, six month after equalisation, Fig. 1). At each sampling date, we collected the top three centimetres of Sphagnum stems. The samples were refrigerated on the same day at $4^{\circ} \mathrm{C}$, fixed with Glutaraldehyde $5 \%\left(\mathrm{C}_{5} \mathrm{H}_{8} \mathrm{O}_{2}\right)$ on the same or the day after, and stored at $4^{\circ} \mathrm{C}$ in the dark until the extraction. Sample codes indicate treatment, replicate and sampling date, e.g. D4_R2 corresponds dry treatment, replicate 4 sampled on 24/09/2015.

\section{Testate amoeba isolation and characterization}

Testate amoebae were extracted by sieving and back-sieving through mesh filters (15-200 $\mu \mathrm{m}$, Booth et al. 2010; Jassey et al. 2011). We aimed for minimum counts of 100 individuals per sample with living and empty tests pooled together. In some plots, especially where the structure of the moss carpet had been degraded by the experimental conditions, testate amoeba density was very low and less than 50 individuals were counted (D2 D1: 47 ind.; D4_D1: 29 ind.; W2_D1: 28 ind.; W2_R1: 17 ind.). Identification was based on the keys of Charman et al. (2000) and Mitchell (2003) at the species or species complex level. Some taxa were grouped into broader morphological groups, in particular taxa from the $\mathrm{Ne}$ bela tincta group (Kosakyan et al. 2013). Cyclopyxis arcelloides includes Cyclopyxis kahli (found only in one sample at R2) and C. eurystoma. Heleopera sylvatica includes $H$. petricola. To reduce the impact of rare species, taxa that did not exceed a mean of $3 \%$ in one treatment at one sampling time $(\mathrm{n}=5)$ were not included in the analyses (Argynnia dentistoma, Assulina seminulum, Bullinularia indica, Cryptodifflugia sacculus, Heleopera sphagni, Hyalosphenia elegans, Plagiopyxis labiata, Sphenoderia lenta, Trigonopyxis arcula, Trinema complanatum and Wailesella eboracencis).

\section{Functional traits}

To be truly functional, traits should be directly or indirectly related to known processes or at least strongly expected to follow change in niche dimension (Lavorel and Garnier 2002; Messier et al. 2010; Mlambo 2014). We selected traits expected to indicated adaptations to water stress (response traits) and traits which are known to impact on food web structure (effect traits, Table 1). Test compression, an aperture in a ventral position and small biovolume allow amoebae to stay active in thin water films (Laggoun-Defarge et al. 2008; Fournier et al. 2012; Tsyganov et al. 2012). Mixotrophy is believed to be an adaptation to low nutrient availability (Fournier et al. 2012; Jassey et al. 2013a) while test material informs on the abundance of mineral particles or prey incorporated in test construction (Gilbert et al. 2003; Gilbert and Mitchell 2006; Jassey et al. 2011; Schwind et al. 2016). Finally, aperture size has been demonstrated to be correlated to prey size and thus the trophic level, small apertures corresponding to microbial feeder and large apertures to predator of micro-eukaryotes and micro-metazoan (Jassey et al. 2013a; Gomaa et al. 2014). Morphological dimensions were measured directly at $400 \times$ magnification, on a subset of ten randomly chosen individuals, using an inverted IX-81 Olympus microscope, and the Olympus cellSens dimension software. Biovolume was calculated according to the general shape of the shell, applying the formulas of Fournier et al. (2015).

\section{Numerical analyses}

\section{Gradient analyses}

The structure and temporal changes of the testate amoeba communities in the three treatments was first assessed based on the relative abundance of species over time. To illustrate the change in each community structure in response to the treatment, species were classified according to their optimal water table depth. These optima were calculated with a transfer function (weighted averaging regression) based on an independent dataset (Mitchell et al. 1999), in which the Creux de l'Epral bog was included.

We then computed the community weighted mean (CWM) of selected traits (biovolume, aperture position, test compression, test composition, mixotrophy and aperture size) in each sample. CWM represented the average of each trait value weighted by the relative abundance of each species (Dray and Legendre 2008; Ricotta and Moretti 2011).

We analysed the temporal patterns of community structure and community weighted mean of functional traits using principal component analyses (PCA) in which we passively projected treatment and time. Prior to PCA, the species dataset was Hellinger transformed according to Legendre and Gallagher (2001) and the CWM of traits dataset was standardised. Permutational multivariate analysis of variance (PERMANOVA) was used to assess the difference in testate amoeba community structure between sampling times for each treatment separately. This analysis partitions dissimilarities between groups and tests the significance of those partitioning (Anderson 2001; Oksanen 2015). We used a Bray-Curtis distance matrix of relative abundance of species with 999 permutations. The significance of any difference between sampling occasions for community weighted mean of traits was tested by analyses of variance with random effect and Tukey multiple comparisons of mean (Bonferroni correction), for each treatment separately.

\section{Null models for functional diversity}

Two main processes may drive community assembly processes (and hence explain community structure): change in niche dimension (habitat selection) and competition between species (biotic in- 

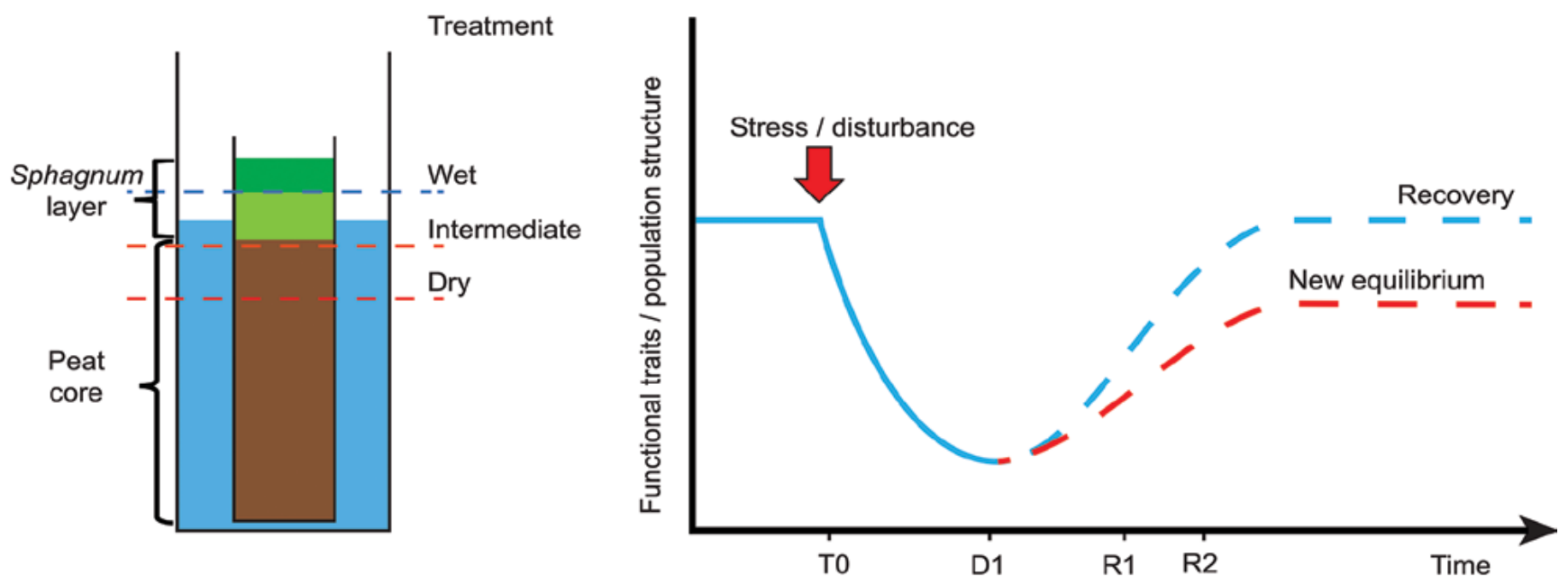

Fig. 1. Left: schematic cross-section through a mesocosm showing the peat and Sphagnum layer. Right: expected evolution of community structure or traits over the stress and recovery phases. At the onset of the experiment (T0) the community included the whole range of species living in pool, lawn and hummock, taken in a natural Sphagnum peatland. D1 is the point of maximum disturbance effect and R1 and R2 are sampling points during the recovery phase. Dotted lines represented the possible evolution of both species community structure and community weighted mean of functional traits in response to disturbance. Full recovery depended on the survival potential of species. The new equilibrium represents the situation when the local conditions or present species pool do not allow a fully recovery of original state. In our case this is due to the fact that some species are likely to be lost during the disturbance phase.

teraction). To disentangle these two processes, recent studies have suggested using null models (Webb et al. 2006; Mason et al. 2008; Cavender-Bares et al. 2009; Chase et al. 2011). As the niche dimension could be inferred from the community weighted mean of traits (Kearney et al. 2010), measuring the distance between the CWM calculated with the real dataset and a CWM constructed with a random community should indicate if the ongoing processes are related to habitat selection or to biotic interaction. The standardized effect size of mean pairwise distance (ses.mpd) compares the observed distance separating samples based on species community structure in relation with the pool of functional traits, and the same distance based on a random community matrix with respect to the species richness of the original community and the original traits matrix (Kembel et al. 2010). The standardized effect size is calculated by:

$$
\text { ses.mpd }=\frac{\text { mean }\left(M_{\text {null }}\right)-M_{\text {observed }}}{s d\left(M_{\text {null }}\right)}
$$

where $M_{\text {null }}=$ randomized mean pairwise distance, $M_{\text {observed }}=$ observed pairwise distance, $s d\left(M_{\text {null }}\right)=$ standard deviation of randomized pairwise distance (Kembel et al. 2010). When ses.mpd is significantly lower than expected by chance, the main drivers of community structure are related to habitat filtering; when it is significantly higher, biotic factors are more likely to be the driver. As the trait matrix included binary variables, semi-quantitative factors and quantitative traits, the Gower distance was applied, using the method of Podani (1999) for ordinal variables (Gower 1971).

All analyses were carried out with the $\mathrm{R}$ statistical software (R Core Team 2016). Ordinations were computed using the pack- age vegan (Oksanen 2015). The community weighted mean of functional traits was calculated using the package FD (Laliberté et al. 2014). Standardized effect size and null models were computed with package Picante (Kembel et al. 2010) and optima and tolerance of species were calculated with the package rioja (Juggins 2015).

\section{RESULTS}

\section{Testate amoeba community composition and treat- ment effects on community structure}

We identified a total of 26 testate amoeba morphotaxa in the 60 analysed samples (Table 2). Hyalosphenia papilio was the only taxon found in all samples and the most abundant overall, accounting for over half for the community on average and with a median abundance of $72.9 \%$. Corythion dubium, Nebela tincta s.1., Assulina muscorum, Phryganella acropodia, Centropyxis aculeata, Arcella catinus, Heleopera rosea, and Euglypha ciliata each contributed $>2 \%$ of the overall community and occurred in $>45 \%$ of all samples (Table 2). Eighteen other morphotaxa were less abundant and frequent (Table 2).

The three treatments had contrasted effects on the species richness, relative abundance of individual taxa 


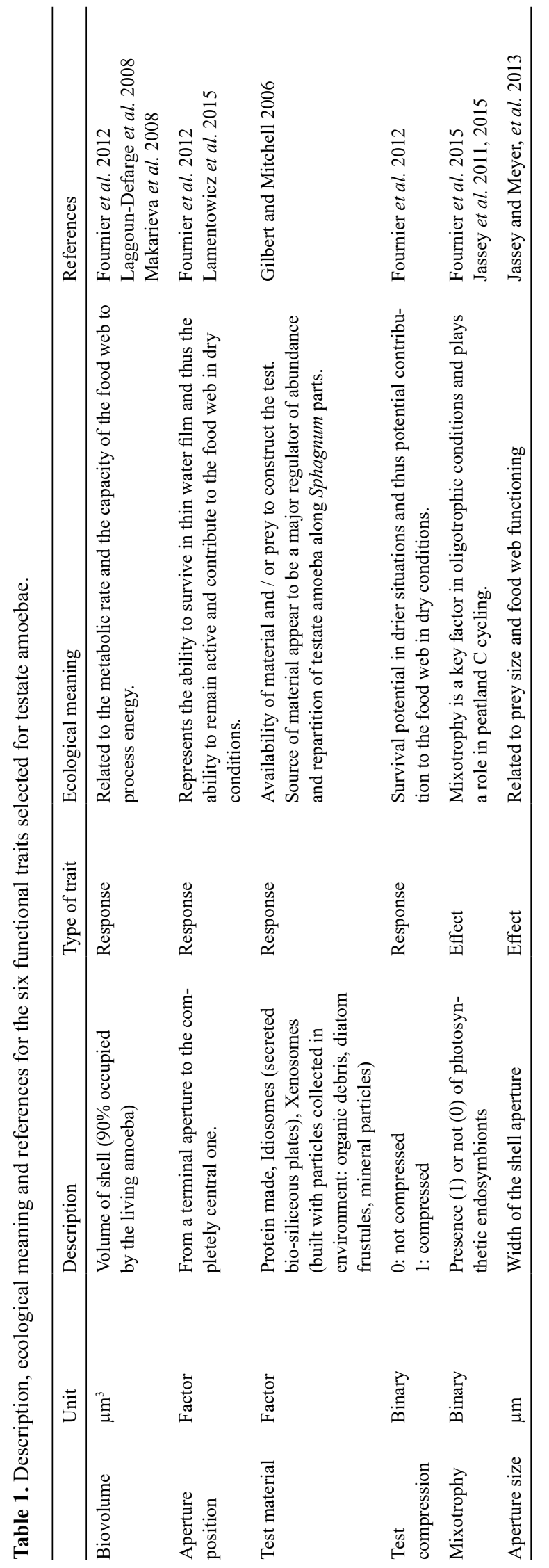

(Table 3) and community structure (Fig. 2a). At T0 communities were strongly dominated by $H$. papilio, and did not significantly differ among treatments (Fig. 2a). Within each treatment, the community structure changed significantly over the duration of the whole experiment (multivariate analyse of variance, dry plots $\mathrm{R}^{2}$ : $58.5 \%$, p-value 0.001 ; intermediate plots $\mathrm{R}^{2}: 40.1 \%$, $\mathrm{p}$-value 0.001 ; wet plots $\mathrm{R}^{2}: 36.8 \%$, p-value 0.016 , Table 4 ).

In dry plots, the species richness increased significantly from 5.2 taxa at $\mathrm{T} 0$ to 10.2 taxa at R1 (ANOVA p-adjusted T0-R1: 0.002) and 10.6 taxa at R2 (ANOVA p-adjusted T0-R2: 0.002) and the community structure diverged from the wet and intermediate plots (Fig. 2a, left of the diagram). At D1, the community was dominated by $N$. tincta, H. rosea, and C. dubium. By R1 $H$. papilio declined sharply (to $6.7 \%$ on average) and the community was dominated by C. dubium, N. tincta, and Cryptodifflugia oviformis. By R2, community structure was again similar to that of D1: H. papilio was again more abundant $(23.6 \%)$ and the community was co-dominated by N. tincta (15.2\%), H. rosea $(12.2 \%)$, Physochila griseola, Cyclopyxis arcelloides, C. aculeata and A. muscorum (7.8-8.6\%). This was the most balanced community in the entire experiment.

Species richness did not change significantly between wet and intermediate treatments. The community structure in these two treatments shifted from T0 to D1 with increasing representation of $P$. acropodia and A. muscorum (Fig. 2a, bottom right quadrat of the ordination diagram). At the start of the recovery period, the community structure diverged between two groups of samples. The communities of six samples (I1, I2, I4, I5, W1, W3) were still dominated by $H$. papilio, but to a less extent, together with $A$. muscorum and $P$. acropodia still abundant during the recovery period. The last four samples (I3, W2, W4, W5, labelled on the PCA) diverged towards a dominance of $A$. muscorum and C. dubium and an almost complete desappearance of $H$. papilio (centre of the diagram); the communities in these plots were more similar to those of dry plots at D1 and R1. W2 should be interpreted very carefully at $\mathrm{R} 1$ as only 18 individuals were counted; total count was higher at R2 (117 individuals) but with a different community structure, very close to that of the dry plots.

\section{Treatment effects on testate amoeba functional traits}

The first two axes of the PCA based on the community weighted mean (CWM) of functional traits (Fig. 2b) explained over $80 \%$ of the variance in the data (axis $1=$ 
$59.6 \%$, axis $2=20.7 \%$ ). As axis 2 was significant based on the Kaiser-Guttmann rule (Kaiser 1991) but just not significant according to the broken stick model (MacArthur 1957), we decided to interpret both axes, as broken stick models often underestimate the significance (Cangelosi and Goriely 2007). The three treatments showed contrasting temporal patterns in the CWM ordination space. At T0 all treatments were represented by a high proportion of mixotrophic species (left of the diagram), a compressed, proteinaceous test, with a terminal aperture and a large biovolume, reflecting the dominance of $H$. papilio. In the Intermediate treatment, no strong change was observed. In the wet plots, a shift was observed towards taxa with smaller biovolume and aperture size, tests constructed of xenosomes and idiosomes and a ventral position of the aperture (axis 2). As for the community biplot (Fig. 2a), samples from the wet plots diverged in the recovery phase (R1 and R2). Two plots (W2 and W3) were correlated to a ventralcentral aperture, with non-compressed, idiosomes tests. Two others (W4 and W5) were correlated to small taxa with a small ventral aperture and a test built from xenosomes, while the last one (W1) remained at the centre of the plot. In dry plots, the CWM of traits shifted towards small species, with small, ventral pseudostomes and compressed tests made with xenosomes at D1, corresponding to the maximal effect of the treatment. After restoring the hydrological conditions, the CWM of traits shifted back towards larger species, with a central-ventral aperture and idiosomes tests.

Changes in the standardised effect size of mean pairwise distance (ses.mpd) based on species traits are shown for each plot (Fig. 3). In dry plots, the trend was negative from D1 onwards: all replicates and sampling dates but one showed negative values as compared to the null model, two of these plots being significantly different from the null model. In wet plots, the trend was towards a positive distance from the null model but two samples (W2 and W5) showed the opposite at $\mathrm{R} 2$, again illustrating the high dispersion of responses in this treatment. In intermediate plots, no clear trend was visible.

\section{DISCUSSION}

Our aim was to assess the resilience capacity of the Sphagnum testate amoeba community following an experimental hydrological perturbation which included three treatments. The duration of the disturbance period was long enough (almost three years) to induce a deep change in mesocosm functioning. In dry samples, the mineralisation of peat was obvious and Sphagnum fallax was replaced by other bryophytes, or vascular plants (especially ferns), similar to most drained peatlands in Switzerland (Grosvernier et al. 1997; Graf et al. 2007).

Our results showed that the duration of the perturbation (i.e. thirty-two months) was clearly sufficient to allow both the $S$. fallax moss (i.e. amoeba habitat) and their associated microbial communities (among which testate amoebae) to respond first to the experimental hydrological perturbation and second to the experimental "restoration". Both the testate amoeba community structure and community weighted mean of functional traits reacted within one growing season to conditions comparable to restoration. The response patterns we observed are generally in line with known ecological preferences of species derived from observational and experimental studies (Marcisz et al. 2014).

\section{Community structure and response to water table changes}

At the beginning of the experiment, the community was dominated by Hyalosphenia papilio, a frequently dominant taxon in oligotrophic Sphagnum peatlands and especially $S$. fallax poor-fens (Lamentowicz and Mitchell 2005; Opravilova and Hajek 2006; Jassey et al. 2013b).

In the dry treatment, the community structure shifted by D1, as expected, towards a dominance of taxa characteristic for drier conditions: Nebela tincta s.l., Corythion dubium, Assulina seminulum, Centropyxis aculeate (Mitchell et al. 1999; Bobrov et al. 1999; Lamentowicz and Mitchell 2005; Qin et al. 2013; Amesbury et al. 2016), which is similar to the community structure observed in early stages of spontaneous cutover bog regeneration (Buttler et al. 1996; LaggounDefarge et al. 2008). Simultaneously, Archerella flavum, a mixotrophic taxa characteristic for moderately wet micro-habitats (Mazei et al. 2009), disappeared completely in the dry plots. This effect remained until $\mathrm{R} 1$ and some recovery became clear by R2 (Mitchell et al. 1999, Mazei et al. 2009). The increase in species richness at R1 and R2 suggests that some taxa were not detected at T0, possibly due to the strong dominance of H. papilio, but were recorded at $\mathrm{R} 1$ and $\mathrm{R} 2$ when this species decreased.

Unlike dry plots, neither the intermediate nor the wet treatments showed a clear change in community 
Table 2. List of testate amoeba taxa, number and relative frequency of occurrence, mean, standard error (se), median, minimum and maximum relative abundance. Taxa are ordered by mean relative abundance over the four sampling times and within all treatment $(\mathrm{n}=60)$. Rare taxa (i.e. maximum abundance in any single treatment and time $<3 \%$ ) are indicated in grey and were excluded from numerical analyses.

\begin{tabular}{|c|c|c|c|c|c|c|c|}
\hline Morphotaxa & $\mathrm{N}$ & $\mathrm{n} / \mathrm{N}$ & mean & se & median & $\min$ & $\max$ \\
\hline Hyalosphenia papilio Leidy, 1874 & 60 & $100.0 \%$ & $56.6 \%$ & $4.1 \%$ & $72.9 \%$ & $0.6 \%$ & $94.7 \%$ \\
\hline Corythion dubium Taranek, 1871 & 29 & $48.3 \%$ & $7.1 \%$ & $2.1 \%$ & $0.0 \%$ & $0.0 \%$ & $83.4 \%$ \\
\hline Nebela tincta s.l. (Leidy) sensu Kosadyan and Lara, 2012 & 41 & $68.3 \%$ & $7.0 \%$ & $1.3 \%$ & $2.2 \%$ & $0.0 \%$ & $41.7 \%$ \\
\hline Assulina muscorum Greeff, 1888 & 39 & $65.0 \%$ & $6.7 \%$ & $1.7 \%$ & $1.2 \%$ & $0.0 \%$ & $70.0 \%$ \\
\hline Phryganella acropodia (Hertwig \& Lesser, 1874) Hopkinson, 1909 & 28 & $46.7 \%$ & $4.1 \%$ & $1.0 \%$ & $0.0 \%$ & $0.0 \%$ & $33.3 \%$ \\
\hline Centropyxis aculeata (Ehrenberg, 1838) & 36 & $60.0 \%$ & $3.0 \%$ & $0.8 \%$ & $0.6 \%$ & $0.0 \%$ & $30.8 \%$ \\
\hline Arcella catinus Penard, 1890 & 44 & $73.3 \%$ & $2.9 \%$ & $0.4 \%$ & $1.7 \%$ & $0.0 \%$ & $10.9 \%$ \\
\hline Heleopera rosea Penard, 1890 & 32 & $53.3 \%$ & $2.7 \%$ & $0.7 \%$ & $0.6 \%$ & $0.0 \%$ & $25.2 \%$ \\
\hline Euglypha ciliata type & 37 & $61.7 \%$ & $2.0 \%$ & $0.4 \%$ & $0.7 \%$ & $0.0 \%$ & $13.7 \%$ \\
\hline Cryptodifflugia oviformis Penard, 1902 & 5 & $8.3 \%$ & $1.4 \%$ & $0.7 \%$ & $0.0 \%$ & $0.0 \%$ & $31.6 \%$ \\
\hline Physochila griseola (Wailes \& Penard, 1911) & 13 & $21.7 \%$ & $1.2 \%$ & $0.4 \%$ & $0.0 \%$ & $0.0 \%$ & $17.6 \%$ \\
\hline Cyclopyxis arcelloides (Deflandre, 1929) & 13 & $21.7 \%$ & $1.0 \%$ & $0.6 \%$ & $0.0 \%$ & $0.0 \%$ & $37.7 \%$ \\
\hline Archerella flavum (Archer, 1877) Loeblich and Tappan, 1961 & 10 & $16.7 \%$ & $0.9 \%$ & $0.4 \%$ & $0.0 \%$ & $0.0 \%$ & $16.4 \%$ \\
\hline Amphitrema wrightianum Archer, 1869 & 11 & $18.3 \%$ & $0.8 \%$ & $0.3 \%$ & $0.0 \%$ & $0.0 \%$ & $11.1 \%$ \\
\hline Heleopera sylvatica Penard, 1890 & 14 & $23.3 \%$ & $0.6 \%$ & $0.2 \%$ & $0.0 \%$ & $0.0 \%$ & $8.9 \%$ \\
\hline Pseudodifflugia gracilis Schlumberger, 1845 & 12 & $20.0 \%$ & $0.5 \%$ & $0.2 \%$ & $0.0 \%$ & $0.0 \%$ & $5.9 \%$ \\
\hline Hyalosphenia elegans Leidy, 1874 & 22 & $36.7 \%$ & $0.5 \%$ & $0.1 \%$ & $0.0 \%$ & $0.0 \%$ & $5.1 \%$ \\
\hline Heleopera sphagni Leidy, 1874 & 11 & $18.3 \%$ & $0.5 \%$ & $0.2 \%$ & $0.0 \%$ & $0.0 \%$ & $9.6 \%$ \\
\hline Trinema complanatum Penard, 1890 & 5 & $8.3 \%$ & $0.2 \%$ & $0.1 \%$ & $0.0 \%$ & $0.0 \%$ & $7.4 \%$ \\
\hline Assulina seminulum (Ehrenberg, 1848) & 8 & $13.3 \%$ & $0.1 \%$ & $0.0 \%$ & $0.0 \%$ & $0.0 \%$ & $0.9 \%$ \\
\hline Sphenoderia lenta Schlumberger, 1845 & 3 & $5.0 \%$ & $0.1 \%$ & $0.0 \%$ & $0.0 \%$ & $0.0 \%$ & $1.8 \%$ \\
\hline Bullinularia indica (Penard, 1907) & 3 & $5.0 \%$ & $0.1 \%$ & $0.0 \%$ & $0.0 \%$ & $0.0 \%$ & $2.1 \%$ \\
\hline Plagiopyxis labiata Penard, 1910 & 2 & $3.3 \%$ & $0.0 \%$ & $0.0 \%$ & $0.0 \%$ & $0.0 \%$ & $1.6 \%$ \\
\hline Wailesella eboracencis (Wailes \& Penard, 1911) & 1 & $1.7 \%$ & $0.0 \%$ & $0.0 \%$ & $0.0 \%$ & $0.0 \%$ & $2.4 \%$ \\
\hline Cryptodifflugia sacculus Penard, 1902 & 1 & $1.7 \%$ & $0.0 \%$ & $0.0 \%$ & $0.0 \%$ & $0.0 \%$ & $1.3 \%$ \\
\hline Argynnia dentistoma (Penard, 1890) & 1 & $1.7 \%$ & $0.0 \%$ & $0.0 \%$ & $0.0 \%$ & $0.0 \%$ & $0.6 \%$ \\
\hline
\end{tabular}

composition during the disturbance period (T0-D1). It seems that the water level contrast between the intermediate and wet treatments was not high enough to affect the population dynamics of $H$. papilio and the community structure thus remained similar in both treatments until D1. This lack of contrasted response of $H$. papilio between these two treatments is in line with the relatively wide tolerance of these taxon to water level (Table 3) (Lamentowicz et al. 2008; Booth and Meyers 2010; Turner et al. 2013). Previous studies have shown that although $H$. papilio is most frequent in Sphagnumdominated poor fens it could also be found in relatively dry habitats (Heal 1964; Payne et al. 2008). This could be explained by the presence of cryptic species inside the H. papilio morphological taxon (Heger et al. 2013; Mulot et al. 2017) with different ecological preferences.

During the recovery phase, with a mean water table position at $-10 \mathrm{~cm}$, the relative abundance of $H$. papilio declined and that of several taxa related to drier conditions (i.e. Assulina muscorum, Phryganella acropodia, Mitchell et al. 1999; Bobrov et al. 1999) increased (Fig. 4). However, two patterns were observed (Fig 2a): the community structure of some wet and intermediate plots changed and became similar to that of the dry treatment, while the other wet and intermediate plots remained relatively stable during this phase, despite 
198 I. Koenig et al.
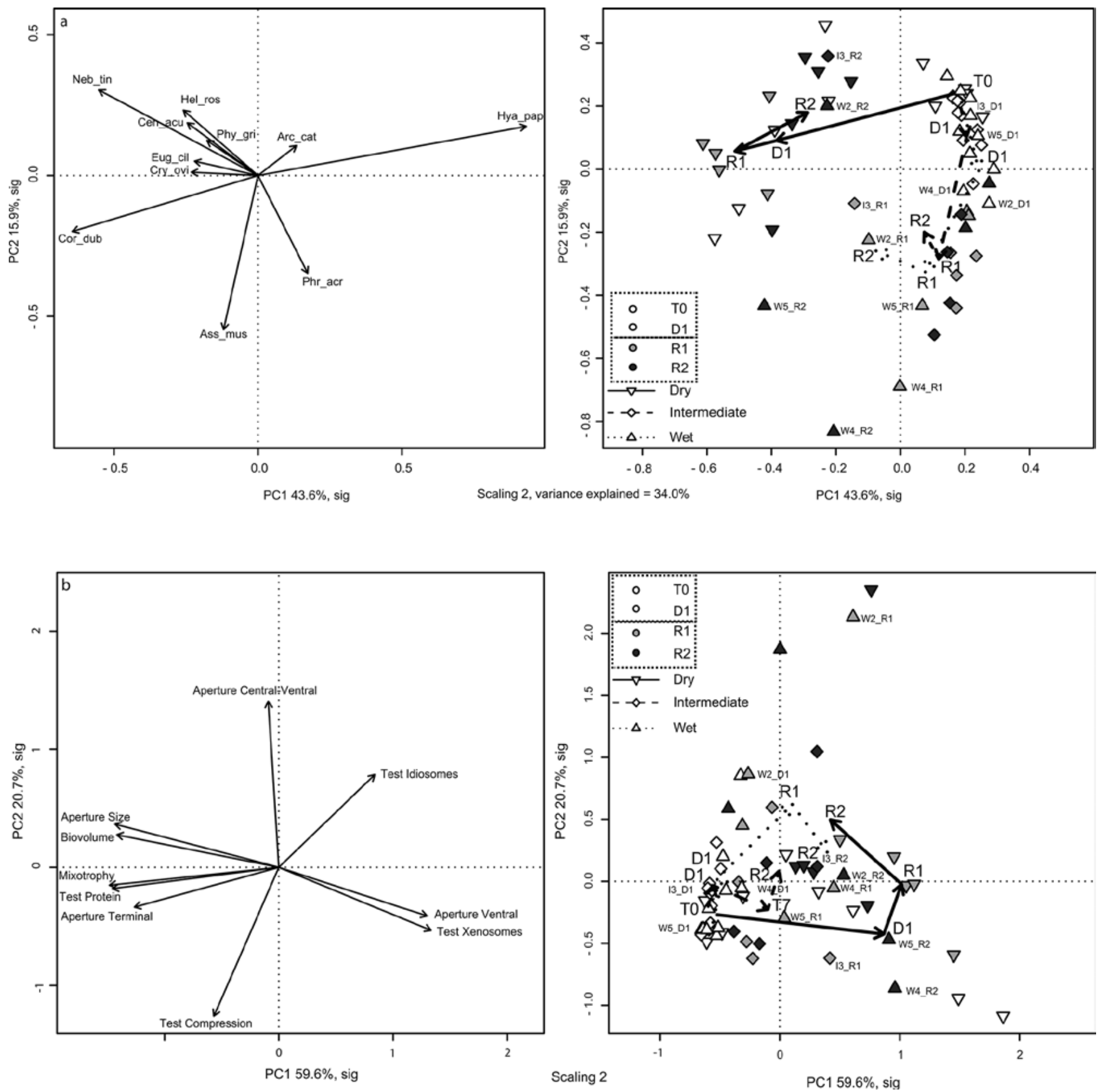

Fig. 2. Principal component analyses (PCA) of a) testate amoeba species and b) community weighted mean (CWM) of functional traits in Sphagnum fallax from a mesocosm experiment simulating water table changes. The species dataset was Hellinger transformed and the CWM data were scaled. Projection of descriptors (left) and samples (right), scaling 2. On the right plots, arrows represent the time line for each treatment (mean coordinates of the five sampling plots of each treatment and time). In both PCAs, axes 1 and 2 were the only significant axes and accounted respectively for $60.4 \%$ (species based) and $80.2 \%$ (CWM based) of the variance. Characteristic plots for wet and intermediate treatments were labelled. Taxa abbreviations: Amp_wri: Amphitrema wrightianum, Pse_gra: Pseudodifflugia gracilis, Arc_fla: Archerella flavum, Cyc_arc: Cyclopyxis arcelloides, Phy_gri: Physochila griseola, Hya_pap: Hyalosphenia papilio, Cen_acu: Centropyxis aculeata, Hel_syl: Heleopera sylvatica, Cry_ovi: Cryptodifflugia oviformis, Eug_cil: Euglypha ciliata, Phr_acr: Phryganella acropodia, Hel_ros: Heleopera rosea, Cor_dub: Corythion dubium, Neb_tin: Nebela tincta s.1., Arc_cat: Arcella catinus, Ass_mus: Assulina muscorum. 
Table 3. Mean relative abundance and standard error $(\mathrm{se}, \mathrm{n}=5)$ and species richness of testate amoeba taxa in Sphagnum fallax from a mesocosm experiment at four sampling time, detail for the three treatments (dry, intermediate, and wet). T0: onset of the experiment, D1: after eight months of treatment, R1 and R2: after three, and six months maintaining the water level $-10 \mathrm{~cm}$. Taxa are listed in increasing water table depth optimum (Opt). The difference in mean species richness was only significant in the dry treatment between T0-R1 and T0-R2 (ANOVA and Tukey HSD test, in bold).

\begin{tabular}{|c|c|c|c|c|c|c|c|c|c|c|c|}
\hline \multirow[b]{2}{*}{ Morphotaxa } & \multirow[b]{2}{*}{ Opt. } & \multirow[b]{2}{*}{ Tol. } & \multirow[b]{2}{*}{ Treat. } & \multicolumn{2}{|c|}{ T0 } & \multicolumn{2}{|c|}{ D1 } & \multicolumn{2}{|c|}{$\mathrm{R} 1$} & \multicolumn{2}{|c|}{$\mathrm{R} 2$} \\
\hline & & & & Mean & se & Mean & se & Mean & se & Mean & se \\
\hline Amphitrema wrightianum & 9.4 & 4.1 & Wet & $0.0 \%$ & $0.0 \%$ & $3.1 \%$ & $0.4 \%$ & $6.1 \%$ & $2.4 \%$ & $0.5 \%$ & $0.5 \%$ \\
\hline Pseudodifflugia gracilis & 9.4 & 7.5 & Wet & $0.0 \%$ & $0.0 \%$ & $0.0 \%$ & $0.0 \%$ & $0.4 \%$ & $0.4 \%$ & $1.0 \%$ & $0.7 \%$ \\
\hline Archerella flavum & 10.9 & 8.5 & Wet & $4.7 \%$ & $2.2 \%$ & $0.0 \%$ & $0.0 \%$ & $0.0 \%$ & $0.0 \%$ & $0.1 \%$ & $0.1 \%$ \\
\hline Cyclopyxis arcelloides & 11.1 & 9.2 & Wet & $0.6 \%$ & $0.3 \%$ & $0.0 \%$ & $0.0 \%$ & $0.0 \%$ & $0.0 \%$ & $0.0 \%$ & $0.0 \%$ \\
\hline Physochila griseola & 15.2 & 7.1 & Wet & $0.0 \%$ & $0.0 \%$ & $0.0 \%$ & $0.0 \%$ & $0.0 \%$ & $0.0 \%$ & $1.2 \%$ & $0.9 \%$ \\
\hline Hyalosphenia papilio & 16.1 & 10.1 & Wet & $85.0 \%$ & $3.9 \%$ & $84.4 \%$ & $3.5 \%$ & $55.5 \%$ & $11.2 \%$ & $36.1 \%$ & $14.6 \%$ \\
\hline Centropyxis aculeata & 17.0 & 7.0 & Wet & $0.8 \%$ & $0.5 \%$ & $1.7 \%$ & $1.5 \%$ & $1.3 \%$ & $1.2 \%$ & $7.1 \%$ & $6.4 \%$ \\
\hline Cryptodifflugia oviformis & 19.5 & 13.2 & Wet & $0.0 \%$ & $0.0 \%$ & $0.0 \%$ & $0.0 \%$ & $0.0 \%$ & $0.0 \%$ & $0.0 \%$ & $0.0 \%$ \\
\hline Euglypha ciliata & 19.6 & 11.8 & Wet & $1.7 \%$ & $0.5 \%$ & $0.4 \%$ & $0.4 \%$ & $0.5 \%$ & $0.4 \%$ & $5.7 \%$ & $2.5 \%$ \\
\hline Phryganella acropodia & 21.6 & 11.5 & Wet & $0.0 \%$ & $0.0 \%$ & $7.4 \%$ & $3.0 \%$ & $17.0 \%$ & $5.2 \%$ & $11.1 \%$ & $6.0 \%$ \\
\hline Heleopera rosea & 22.3 & 6.9 & Wet & $1.2 \%$ & $0.8 \%$ & $1.0 \%$ & $0.6 \%$ & $0.0 \%$ & $0.0 \%$ & $1.9 \%$ & $1.3 \%$ \\
\hline Heleopera sylvatica & 23.0 & 11.9 & Wet & $0.0 \%$ & $0.0 \%$ & $0.0 \%$ & $0.0 \%$ & $0.0 \%$ & $0.0 \%$ & $2.0 \%$ & $0.7 \%$ \\
\hline Corythion dubium & 23.7 & 11.0 & Wet & $0.0 \%$ & $0.0 \%$ & $0.0 \%$ & $0.0 \%$ & $6.4 \%$ & $1.8 \%$ & $4.2 \%$ & $2.4 \%$ \\
\hline Nebela tincta s.l. & 23.8 & 12.7 & Wet & $1.8 \%$ & $0.6 \%$ & $0.3 \%$ & $0.3 \%$ & $1.2 \%$ & $1.2 \%$ & $4.4 \%$ & $3.0 \%$ \\
\hline Arcella catinus & 24.7 & 8.7 & Wet & $3.5 \%$ & $1.4 \%$ & $1.1 \%$ & $0.7 \%$ & $1.4 \%$ & $1.1 \%$ & $1.8 \%$ & $0.8 \%$ \\
\hline Assulina muscorum & 25.5 & 11.4 & Wet & $0.7 \%$ & $0.5 \%$ & $0.6 \%$ & $0.4 \%$ & $10.2 \%$ & $7.3 \%$ & $22.9 \%$ & $14.3 \%$ \\
\hline Specific richness & & & & 6.6 & 0.7 & 4.8 & 0.6 & 5.8 & 0.6 & 8.2 & 1.5 \\
\hline Amphitrema wrightianum & 9.4 & 4.1 & Inter & $0.0 \%$ & $0.0 \%$ & $0.0 \%$ & $0.0 \%$ & $0.0 \%$ & $0.0 \%$ & $0.1 \%$ & $0.1 \%$ \\
\hline Pseudodifflugia gracilis & 9.4 & 7.5 & Inter & $0.0 \%$ & $0.0 \%$ & $0.0 \%$ & $0.0 \%$ & $0.0 \%$ & $0.0 \%$ & $0.7 \%$ & $0.7 \%$ \\
\hline Archerella flavum & 10.9 & 8.5 & Inter & $0.0 \%$ & $0.0 \%$ & $0.0 \%$ & $0.0 \%$ & $0.3 \%$ & $0.3 \%$ & $1.8 \%$ & $1.2 \%$ \\
\hline Cyclopyxis arcelloides & 11.1 & 9.2 & Inter & $0.2 \%$ & $0.1 \%$ & $0.0 \%$ & $0.0 \%$ & $0.2 \%$ & $0.2 \%$ & $1.4 \%$ & $1.2 \%$ \\
\hline Physochila griseola & 15.2 & 7.1 & Inter & $0.0 \%$ & $0.0 \%$ & $0.2 \%$ & $0.2 \%$ & $0.0 \%$ & $0.0 \%$ & $0.9 \%$ & $0.9 \%$ \\
\hline Hyalosphenia papilio & 16.1 & 10.1 & Inter & $87.2 \%$ & $2.7 \%$ & $84.2 \%$ & $1.1 \%$ & $68.2 \%$ & $4.8 \%$ & $56.2 \%$ & $8.0 \%$ \\
\hline Centropyxis aculeata & 17.0 & 7.0 & Inter & $0.9 \%$ & $0.2 \%$ & $0.5 \%$ & $0.2 \%$ & $0.6 \%$ & $0.5 \%$ & $4.3 \%$ & $4.3 \%$ \\
\hline Cryptodifflugia oviformis & 19.5 & 13.2 & Inter & $0.0 \%$ & $0.0 \%$ & $0.0 \%$ & $0.0 \%$ & $0.0 \%$ & $0.0 \%$ & $0.0 \%$ & $0.0 \%$ \\
\hline Euglypha ciliata & 19.6 & 11.8 & Inter & $0.1 \%$ & $0.1 \%$ & $0.5 \%$ & $0.2 \%$ & $0.3 \%$ & $0.2 \%$ & $0.4 \%$ & $0.3 \%$ \\
\hline Phryganella acropodia & 21.6 & 11.5 & Inter & $0.0 \%$ & $0.0 \%$ & $2.6 \%$ & $1.6 \%$ & $5.3 \%$ & $3.1 \%$ & $6.1 \%$ & $3.7 \%$ \\
\hline Heleopera rosea & 22.3 & 6.9 & Inter & $0.5 \%$ & $0.5 \%$ & $1.1 \%$ & $0.6 \%$ & $0.3 \%$ & $0.3 \%$ & $1.3 \%$ & $1.2 \%$ \\
\hline Heleopera sylvatica & 23.0 & 11.9 & Inter & $0.0 \%$ & $0.0 \%$ & $0.0 \%$ & $0.0 \%$ & $0.2 \%$ & $0.2 \%$ & $0.9 \%$ & $0.5 \%$ \\
\hline Corythion dubium & 23.7 & 11.0 & Inter & $0.2 \%$ & $0.2 \%$ & $0.0 \%$ & $0.0 \%$ & $6.6 \%$ & $6.0 \%$ & $1.3 \%$ & $0.8 \%$ \\
\hline Nebela tincta s.l. & 23.8 & 12.7 & Inter & $3.6 \%$ & $0.6 \%$ & $2.0 \%$ & $0.7 \%$ & $1.4 \%$ & $1.4 \%$ & $4.0 \%$ & $3.5 \%$ \\
\hline Arcella catinus & 24.7 & 8.7 & Inter & $6.6 \%$ & $2.0 \%$ & $7.1 \%$ & $1.1 \%$ & $1.4 \%$ & $0.5 \%$ & $3.0 \%$ & $0.8 \%$ \\
\hline Assulina muscorum & 25.5 & 11.4 & Inter & $0.8 \%$ & $0.2 \%$ & $1.8 \%$ & $0.7 \%$ & $15.2 \%$ & $3.3 \%$ & $17.4 \%$ & $4.9 \%$ \\
\hline Specific richness & & & & 5.8 & 0.5 & 6.0 & 0.3 & 6.6 & 0.5 & 7.6 & 1.5 \\
\hline Amphitrema wrightianum & 9.4 & 4.1 & Dry & $0.0 \%$ & $0.0 \%$ & $0.0 \%$ & $0.0 \%$ & $0.0 \%$ & $0.0 \%$ & $0.0 \%$ & $0.0 \%$ \\
\hline Pseudodifflugia gracilis & 9.4 & 7.5 & Dry & $0.0 \%$ & $0.0 \%$ & $0.0 \%$ & $0.0 \%$ & $1.1 \%$ & $0.6 \%$ & $3.4 \%$ & $0.8 \%$ \\
\hline Archerella flavum & 10.9 & 8.5 & Dry & $4.6 \%$ & $3.2 \%$ & $0.0 \%$ & $0.0 \%$ & $0.0 \%$ & $0.0 \%$ & $0.0 \%$ & $0.0 \%$ \\
\hline Cyclopyxis arcelloides & 11.1 & 9.2 & Dry & $0.4 \%$ & $0.4 \%$ & $0.0 \%$ & $0.0 \%$ & $1.1 \%$ & $1.1 \%$ & $8.4 \%$ & $7.6 \%$ \\
\hline Physochila griseola & 15.2 & 7.1 & Dry & $0.0 \%$ & $0.0 \%$ & $1.1 \%$ & $0.9 \%$ & $2.9 \%$ & $1.7 \%$ & $8.6 \%$ & $3.5 \%$ \\
\hline Hyalosphenia papilio & 16.1 & 10.1 & Dry & $81.7 \%$ & $5.7 \%$ & $17.1 \%$ & $6.1 \%$ & $6.7 \%$ & $2.6 \%$ & $23.6 \%$ & $6.6 \%$ \\
\hline Centropyxis aculeata & 17.0 & 7.0 & Dry & $0.5 \%$ & $0.4 \%$ & $7.7 \%$ & $5.1 \%$ & $2.8 \%$ & $1.1 \%$ & $8.2 \%$ & $1.9 \%$ \\
\hline Cryptodifflugia oviformis & 19.5 & 13.2 & Dry & $0.0 \%$ & $0.0 \%$ & $0.0 \%$ & $0.0 \%$ & $18.3 \%$ & $5.9 \%$ & $0.0 \%$ & $0.0 \%$ \\
\hline Euglypha ciliata & 19.6 & 11.8 & Dry & $1.8 \%$ & $0.8 \%$ & $4.5 \%$ & $2.1 \%$ & $4.2 \%$ & $1.7 \%$ & $5.0 \%$ & $1.2 \%$ \\
\hline
\end{tabular}




\begin{tabular}{|c|c|c|c|c|c|c|c|c|c|c|c|}
\hline \multirow[b]{2}{*}{ Morphotaxa } & \multirow[b]{2}{*}{ Opt. } & \multirow[b]{2}{*}{ Tol. } & \multirow[b]{2}{*}{ Treat. } & \multicolumn{2}{|c|}{ T0 } & \multicolumn{2}{|c|}{ D1 } & \multicolumn{2}{|c|}{$\mathrm{R} 1$} & \multicolumn{2}{|c|}{$\mathrm{R} 2$} \\
\hline & & & & Mean & se & Mean & se & Mean & se & Mean & se \\
\hline Phryganella acropodia & 21.6 & 11.5 & Dry & $0.0 \%$ & $0.0 \%$ & $0.0 \%$ & $0.0 \%$ & $0.0 \%$ & $0.0 \%$ & $0.7 \%$ & $0.3 \%$ \\
\hline Heleopera rosea & 22.3 & 6.9 & Dry & $0.7 \%$ & $0.3 \%$ & $9.2 \%$ & $5.3 \%$ & $3.7 \%$ & $0.8 \%$ & $12.2 \%$ & $2.6 \%$ \\
\hline Heleopera sylvatica & 23.0 & 11.9 & Dry & $0.0 \%$ & $0.0 \%$ & $0.0 \%$ & $0.0 \%$ & $1.3 \%$ & $1.0 \%$ & $3.1 \%$ & $1.7 \%$ \\
\hline Corythion dubium & 23.7 & 11.0 & Dry & $0.7 \%$ & $0.7 \%$ & $33.9 \%$ & $16.5 \%$ & $30.1 \%$ & $9.4 \%$ & $3.5 \%$ & $1.7 \%$ \\
\hline Nebela tincta s.l. & 23.8 & 12.7 & Dry & $4.3 \%$ & $1.9 \%$ & $22.2 \%$ & $5.9 \%$ & $24.8 \%$ & $6.6 \%$ & $15.2 \%$ & $1.8 \%$ \\
\hline Arcella catinus & 24.7 & 8.7 & Dry & $5.3 \%$ & $2.0 \%$ & $1.9 \%$ & $0.8 \%$ & $1.2 \%$ & $0.8 \%$ & $0.4 \%$ & $0.2 \%$ \\
\hline Assulina muscorum & 25.5 & 11.4 & Dry & $0.0 \%$ & $0.0 \%$ & $2.3 \%$ & $0.7 \%$ & $1.9 \%$ & $0.9 \%$ & $7.8 \%$ & $5.3 \%$ \\
\hline Specific richness & & & & 5.2 & 0.9 & 7.4 & 0.4 & 10.2 & 0.7 & 10.6 & 0.5 \\
\hline
\end{tabular}

Table 4. Permutational multivariate analysis of variance of testate amoeba community dataset from Sphagnum fallax mesocosm experiment simulating water table level changes by treatment and between sampling time. Sampling time was significantly different in all treatments.

\begin{tabular}{|c|c|c|c|c|c|c|c|}
\hline Treatment & & Df & SumsOfSqs & MeanSqs & F-value & $\mathrm{R}^{2}$ & p-value \\
\hline \multirow[t]{3}{*}{ Dry } & Time & 3 & 2.34 & 0.78 & 7.52 & 0.585 & 0.001 \\
\hline & Residuals & 16 & 1.66 & 0.10 & & 0.415 & \\
\hline & Total & 19 & 4.00 & & & 1 & \\
\hline \multirow[t]{3}{*}{ Intermediate } & Time & 3 & 0.37 & 0.12 & 3.56 & 0.401 & 0.001 \\
\hline & Residuals & 16 & 0.55 & 0.03 & & 0.599 & \\
\hline & Total & 19 & 0.92 & & & 1 & \\
\hline \multirow[t]{3}{*}{ Wet } & Time & 3 & 0.88 & 0.29 & 3.11 & 0.368 & 0.016 \\
\hline & Residuals & 16 & 1.51 & 0.09 & & 0.632 & \\
\hline & Total & 19 & 2.39 & & & 1 & \\
\hline
\end{tabular}

$\mathrm{Df}$ - degree of freedom, SumOfSqs - sequencial sum of square, MeanSqs - mean square.

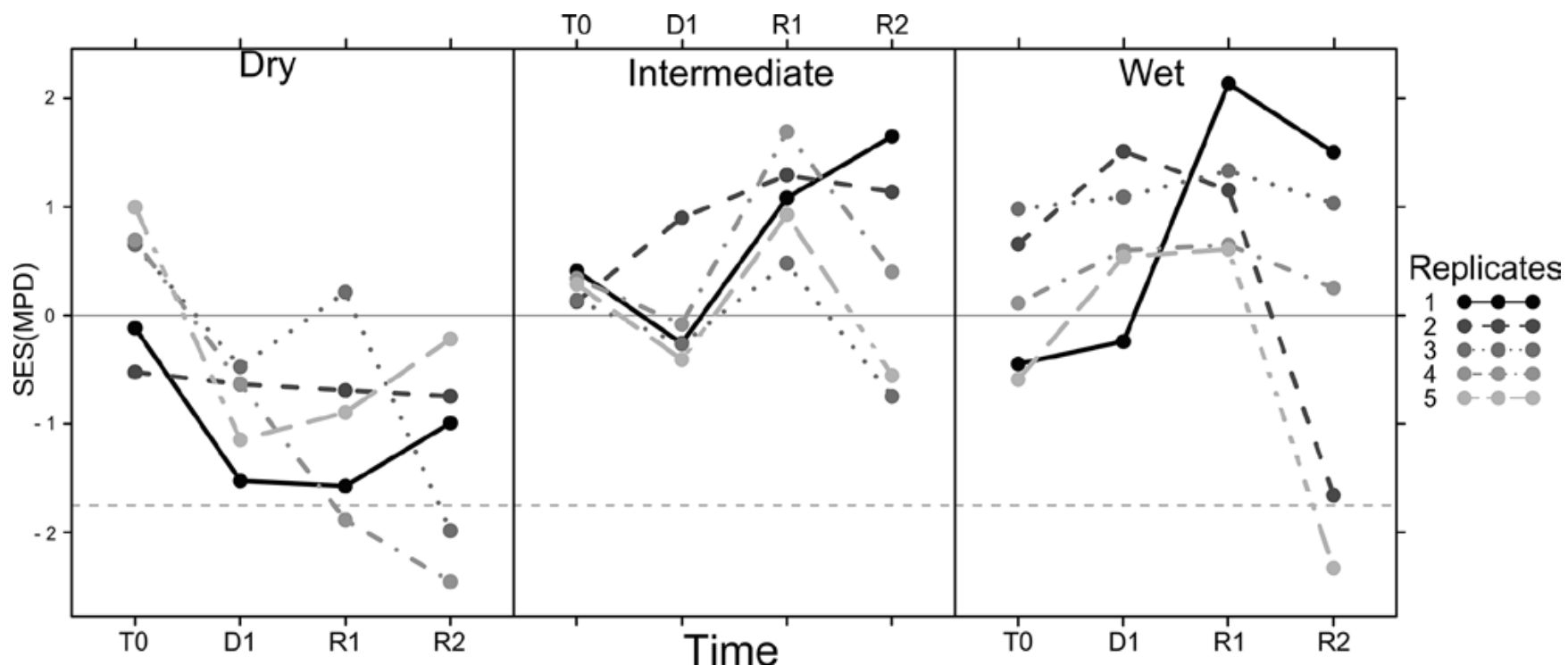

Fig. 3. Evolution of standardized effect size of mean pairwise distance between sampling plots relatively to a null model (random species matrix with respect to observed species richness, see text for details) of testate amoeba community weighted mean (CWM) of functional trait data from a Sphagnum fallax mesocosm experiment simulating water table changes. The mean pairwise distance represents the distance separating communities based on the pool of functional traits. Horizontal grey dotted line represents p-value of 0.05 , points below the line are significantly different from the null model. Each replicate was represented separately, with a grey scale. 
a decrease of $H$. papilio. This unexpected trend is however coherent with the contrasted evolution of the mesocosms (Suppl. Fig. 1-3). Indeed, when the water level was moved to $-10 \mathrm{~cm}$ in all plots, we observed that the structure and vitality of the moss carpet had considerably changed in some mesocosms. This was most clear in dry treatments where the $S$. fallax carpet was almost completely dead and partly replaced by other bryophytes and ferns (Suppl. Fig. 2), but a similar situation was also observed in some wet and intermediate plots. At the end of the experiment, S. fallax recovered in most of the plots (Suppl. Fig. 3).

\section{Treatment effects on testate amoeba functional traits}

The clear community shift in the dry treatment corresponded to a shift in traits with an increased representation of smaller taxa, of shells with small ventral pseudostomes, a loss of mixotrophy, and an increase in idiosome and xenosome tests. These changes are in line with the drier conditions and probable thinner water films (Fournier et al. 2015; Payne et al. 2016; Marcisz et al. 2016). The clear decrease in mixotrophy (related to the diminution of $H$. papilio which was not replaced by another mixotrophic taxa) indicates that mixotrophy does not represent an advantage in drier conditions, even when light availability remains constant. Mixotrophy has been shown to be related to nutrient content and $\mathrm{C}$ cycling: a higher proportion of mixotrophs in the community being associated with higher $\mathrm{C}$ fixation (Jassey et al. 2013a, 2015). The reduction of mixotrophy thus indicates a potentially important functional change in the testate amoeba community in the dry plots during the disturbance phase. The shift in traits also indicates a shift from eukaryvory (sensu Lahr et al. 2015, i.e. feeding on Eukaryotes such as protists, micro-metazoa, fungi and eukaryotic microalgae) towards bacterivory, corresponding lowering of the trophic level the community and suggesting a faster turnover of carbon and nutrients (Jassey et al. 2013b, 2015; Fournier et al. 2015). During the recovery phase (R1-R2) in the dry treatment, the shifts of both community structure and traits towards the situation of $\mathrm{T} 0$ are in line with the increased moisture.

The CWMs did not differ significantly between the wet and intermediate treatments. In these two treatments, changes occurred only after D1, with a slow transition towards traits indicating drier conditions, at least in some plots. CWMs of traits further suggest that the vitality status of the Sphagnum layer was the main driver in wet $\&$ intermediate plots (Suppl. Fig. 1) while water table depth more strongly affected the testate amoeba community structure in the dry plots. This is in line with previous observations on the strong role of moisture conditions along the Sphagnum stem in shaping testate amoeba communities: Actual moisture conditions is a more likely driver of community structure than water level (Buttler et al. 1996; Mitchell et al. 1999; Booth 2001, 2002; Jassey et al. 2011; Payne et al. 2016), which also explains why transfer functions typically fail to predict very low water tables (e.g. lower than $30 \mathrm{~cm}$ depth, Mitchell et al. 1999).

\section{Community assembly: habitat filtering vs. biotic factors}

We used the null model approach to disentangle biotic from abiotic drivers of community assembly. Changes in ecological niche should impact on testate amoeba community structure and this will be reflected by the CWM of traits. The distance between sampling plots (mean pairwise distance) should be significantly lower than the random distance in plots where abiotic drivers are more important than competition (Chase et al. 2011; Fournier et al. 2012; Arrieira et al. 2015). In our experiment, the trend in dry plots was negative (significantly in two replicates, Fig. 3) and, indicated that the community structure of testate amoeba was mainly driven by environmental filters (Villéger et al. 2008). The same pattern occurred in two replicates of the wet treatment (W2 and W5), in line with the state of the Sphagnum carpet in these plots. The shift toward reduced water saturation (related to dryness) imply an important constraint for the microbial communities living in Sphagnum and, as one of the most important groups, testate amoeba respond strongly to the change. The loss of mixotrophy and the increase of smaller, mainly bacterivorous taxa indicate a drastic change in ecosystem functioning with deep impact on nutrient and carbon cycling (Jassey et al. 2013a, 2013b; Fournier et al. 2015). Thus, by using CWM of well selected traits, we are able to highlight ongoing processes without prior knowledge on species ecology.

\section{CONCLUSION AND SUGGESTIONS FOR FUTURE WORK}

Our goal was to monitor the response of the testate amoeba community to a water level that had been "restored" to a level comparable to natural Sphagnum 
202 I. Koenig et al.

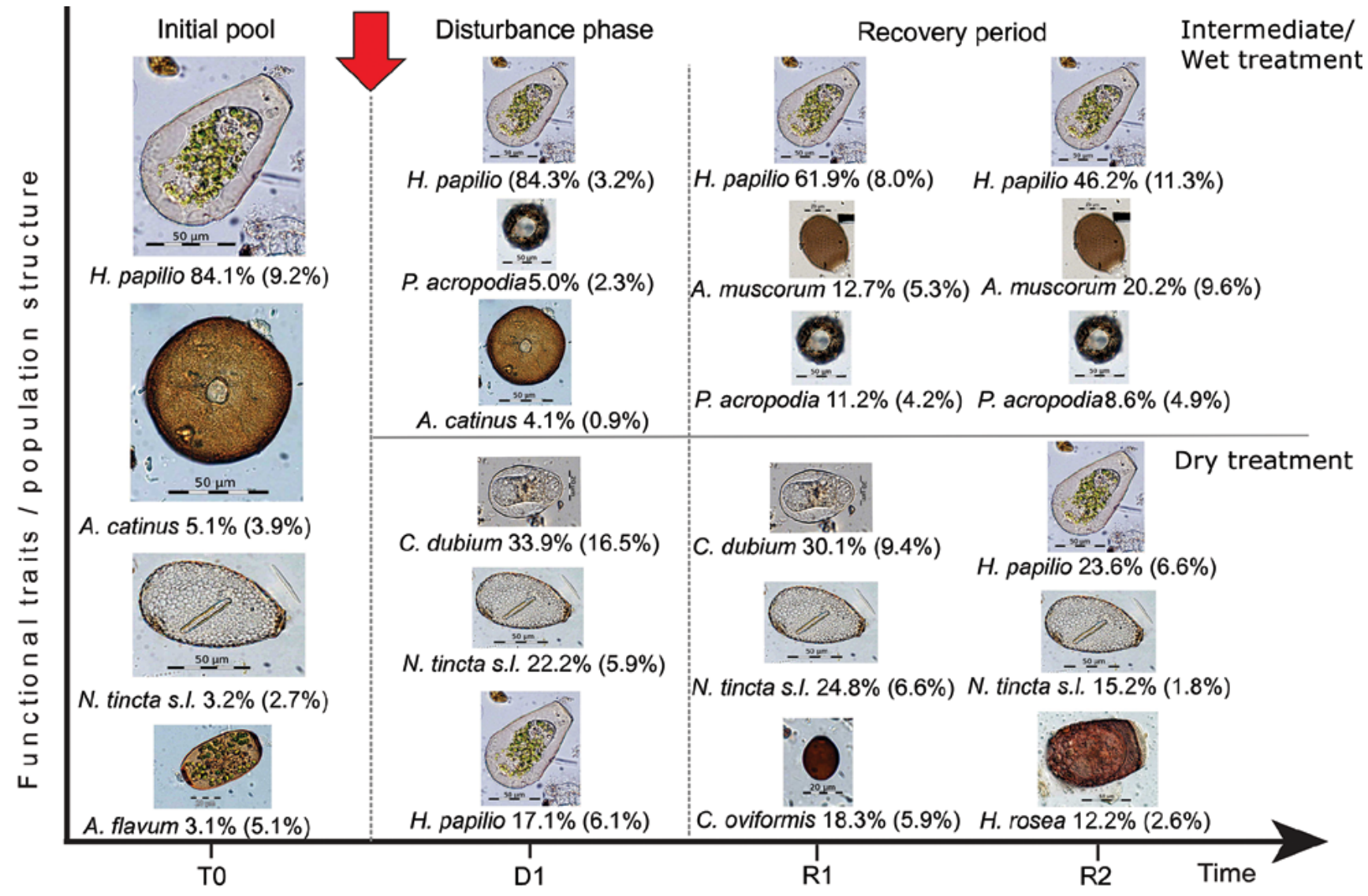

Biovolume

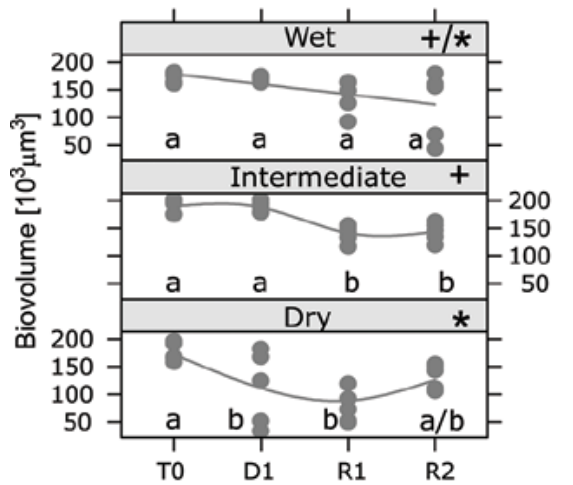

Mixotrophy

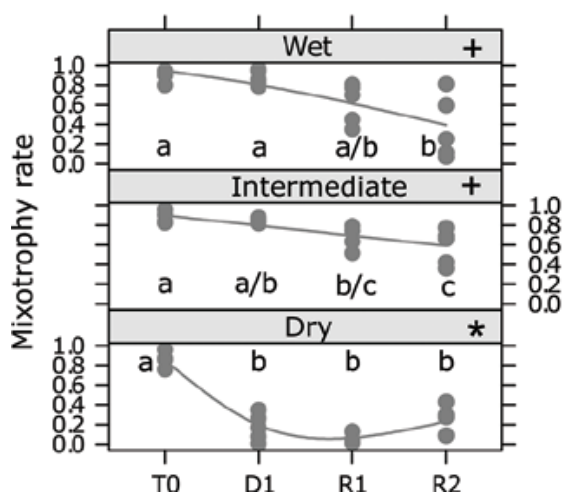

Pseudostome size

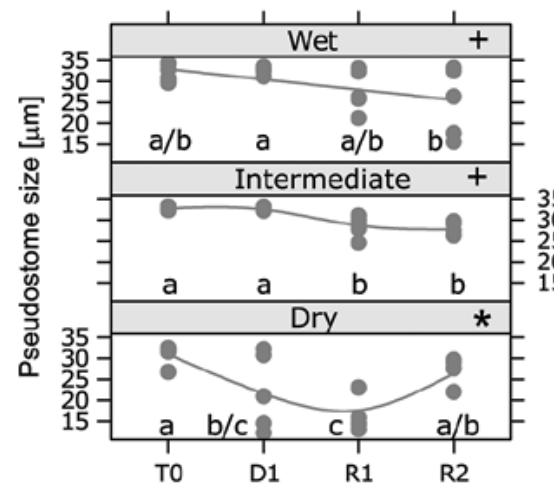

Test compression

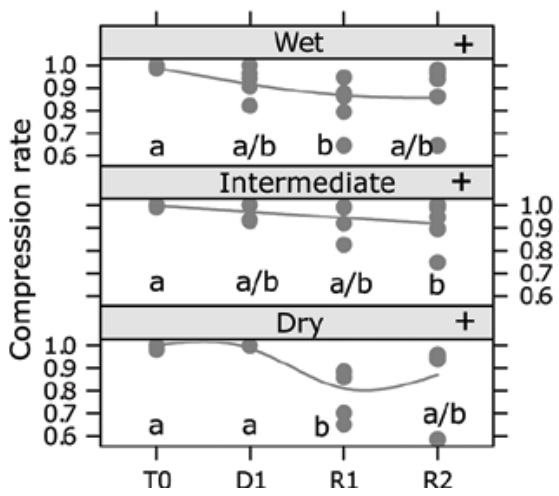

Position of aperture
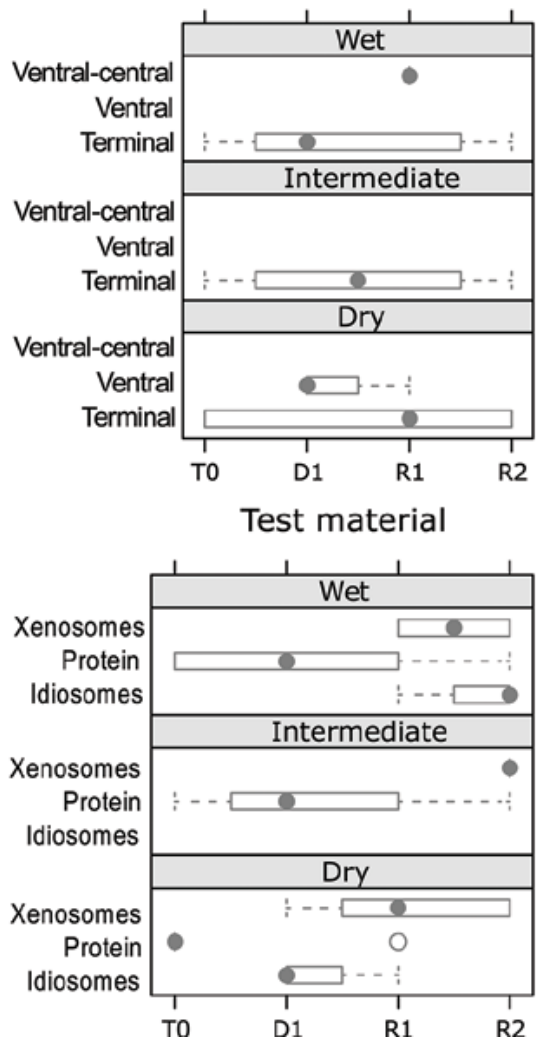
peatlands using a mesocosm experiment. Due to the relatively small diameter of the mesocosms used in our experiment $(12 \mathrm{~cm})$ the survival of Sphagnum mosses cannot be guaranteed. Larger mesocosms would be useful to conduct longer-term experiments, but at a higher cost. The choice of the size is clearly a trade-off. Furthermore, over the course of our experiment, the differential growth of the mosses and mineralization of the underlying peat caused the surface of the moss carpet to strongly diverge among treatments (ca. $20 \mathrm{~cm}$ height difference by the end of the experiment), thus creating additional microclimatic effects (shading). Nevertheless, the survival of testate amoeba communities throughout the experiment, allowed us, for the first time experimentally, to assess community recovery in response to a raise in water level comparable with what is aimed for in peatland restoration projects in open areas. Our study also illustrates the importance of taking into consideration the changes in vegetation and especially the changes in Sphagnum cover. Sphagnum is a well-known keystone genus in peatland ecology. To this date few studies of peatland testate amoebae have explored specifically the difference of testate amoeba communities between Sphagnum and other mosses (e.g. Opravilova and Hajek 2006; Lamentowicz et al. 2011; Lizoňová and Horsák 2017). Our study suggests that where Sphagnum is absent the relationship between testate amoeba communities and water table depth is not the same as in Sphagnum carpet. This question deserves to be studied further.

The response patterns of the community weighted means of functional traits were similar to those of testate amoeba community structure and both were well correlated to ecological constraints. Through the link between the selected traits and the underlying processes, the CWM approach give information on local processes which complemented and sometimes explained the shift in community structure, as noted for the diverging response of some wet/intermediate plots in the recovery phase. In addition, the functional diversity approach circumvents to some extent the need for high taxonomic resolution, which may not be easily achieved for non-specialists and can lead to erroneous interpretation in some cases (Heger et al. 2009; Mitchell et al. 2014). Testate amoeba taxonomy is constantly changing and molecular based studies are revealing cryptic diversity (Lara et al. 2007; Heger et al. 2009; Kosakyan et al. 2013, 2016; Oliverio et al. 2014; Singer et al. 2015). Until a better taxonomy is available, the functional diversity approach, based on easily-measurable morphological traits represents a powerful approach to infer ecological processes (de Bello et al. 2010; Fournier et al. 2012, 2015; Mitchell et al. 2014). Measuring the proportion of mixotrophs, the size and position of the pseudostome or the size category of testate amoebae is thus a promising approach to monitor the impact of perturbations or restoration on Sphagnum peatlands (Fournier et al. 2015; Payne et al. 2016; Marcisz et al. 2016). To our knowledge these tools have not yet been used in environmental consulting or by managers, and it is worth developing them.

Acknowledgments. This experiment was the follow up of a project supported by grant $N^{\circ}$ PSPB-013/2010 from Switzerland through the Swiss Contribution to the enlarged European Union and additional funds from the University of Neuchâtel.

\section{REFERENCES}

Amesbury M. J., Swindles G. T., Bobrov A., Charman D. J., Holden J., Lamentowicz M., Mallon G., Mazei Y., Mitchell E. A. D., Payne R. J., Roland T. P., Turner T. E., Warner B. G. (2016) Development of a new pan-European testate amoeba transfer function for reconstructing peatland palaeohydrology. Quat. Sci. Rev. 152: 132-151

\footnotetext{
Fig. 4. Top: summary representation of the evolution testate amoeba communities from a Sphagnum fallax mesocosm experiment simulating water table changes. The size of illustrated species is approximately to their relative body size. As communities in the intermediate and wet treatments were not significantly different, they are pooled together for the species based evolution (upper part). The three most abundant taxa (mean abundance) at each sampling time are represented (four at T0). Present at the beginning of the experiment, $A$. flavum recovered only slightly in intermediate plots at R2 (not shown). Small taxa (P. acropodia, A. muscorum, C. oviformis, $C$. dubium) increased after the disturbance (arrow) and in dry plots H. papilio almost disappeared at R1 and recovered at R2. Bottom: Evolution of testate amoeba functional traits. Different signs $(+, *)$ or letters indicate significant differences. The lines show the cubic spline interpolation of the CWM of trait at each sampling points $(n=5)$. As shown in the upper graph based on taxonomic community structure, in the wet and intermediate treatments the disturbance effect remained in the recovery phase in some plots, which is indicated by the increasing spread of points and constantly decreasing spline line. By contrast, in dry plots, the maximum stress response was observed at D1 and R1 followed by a partial recovery at R2. In the dry treatment, the dominant positions of the pseudostome was ventral at D1 and terminal at R1.
} 
Anderson M. J. (2001) A new method for non-parametric multivariate analysis of variance: non-parametric manova for ecology. Austral. Ecol. 26: 32-46

Arrieira R. L., Schwind L. T. F., Bonecker C. C., Lansac-Toha F. A. (2015) Use of functional diversity to assess determinant assembly processes of testate amoebae community. Aquat. Ecol. 49: 561-571

de Bello F., Lavorel S., Díaz S., Harrington R., Cornelissen J. H., Bardgett R. D., Berg M. P., Cipriotti P., Feld C. K., Hering D., and others (2010) Towards an assessment of multiple ecosystem processes and services via functional traits. Biodivers. Conserv. 19: $2873-2893$

Benton T. G., Solan M., Travis J. M. J., Sait S. M. (2007) Microcosm experiments can inform global ecological problems. Trends Ecol. Evol. 22: 516-521

Bobrov A. A., Charman D. J., Warner B. G. (1999) Ecology of testate amoebae (Protozoa: Rhizopoda) on peatlands in western Russia with special attention to niche separation in closely related taxa. Protist 150: 125-36

Bonn A., Allott T., Evans M., Joosten H., Stoneman R. (2016) Peatland restoration and ecosystem services: science, policy and practice. Cambridge University Press

Bonnett S. A., Linsted R., Ross S., Maltby E. (2011) Guidelines for monitoring the success of peatland restoration. Technical Report. Natural England, SWIMMER

Booth R. K. (2001) Ecology of testate amoebae (Protozoa) in two Lake Superior coastal wetlands: Implications for paleoecology and environmental monitoring. Wetlands 21: 564-576

Booth R. K. (2002) Testate amoebae as paleoindicators of surfacemoisture changes on Michigan peatlands: modern ecology and hydrological calibration. J. Paleolimnol. 28: 329-348

Booth R. K., Lamentowicz M., Charman D. (2010) Preparation and analysis of testate amoebae in peatland paleoenvironmental studies. Mires Peat 7: 1-7

Booth R. K., Meyers B. (2010) Environmental controls on pore number in Hyalosphenia papilio: implications for paleoenvironmental reconstruction. Acta Protozool. 49: 29-35

Buttler A., Warner B. G., Grosvernier P., Matthey Y. (1996) Vertical patterns of testate amoebae (protozoa: rhizopoda) and peatforming vegetation on cutover bogs in the Jura, Switzerland. New Phytol. 134: 371-382

Cangelosi R., Goriely A. (2007) Component retention in principal component analysis with application to cDNA microarray data. Biol. Direct 2: 2

Caron D. A., Worden A. Z., Countway P. D., Demir E., Heidelberg K. B. (2009) Protists are microbes too: a perspective. ISME J. 3: $4-12$

Cavalier-Smith T., Chao E. E. Y. (2003) Phylogeny and classification of phylum Cercozoa (Protozoa). Protist 154: 341-358

Cavender-Bares J., Kozak K. H., Fine P. V. A., Kembel S. W. (2009) The merging of community ecology and phylogenetic biology. Ecol. Lett. 12: 693-715

Charman D. J. (2001) Biostratigraphic and palaeoenvironmental applications of testate amoebae. Quat. Sci. Rev. 20: 1753-1764

Charman D. J., Hendon D., Woodland W. A. (2000) The identification of testate amoebae (Protozoa: Rhizopoda) in peats. Technical Guide No. 9. Quaternary Research Association.

Chase J. M., Kraft N. J., Smith K. G., Vellend M., Inouye B. D. (2011) Using null models to disentangle variation in community dissimilarity from variation in $\alpha$-diversity. Ecosphere 2: 1-11

Church A., Fish R., Haines-Young R., Mourato S., Tratalos J., Stapleton L., Willis C., Coates P., Gibbons S., Leyshon C.,
Potschin M., Ravenscroft N., Sanchis-Guarner R., Winter M. Kenter J. (2014) UK National Ecosystem Assessment Followon. Work Package Report 5: Cultural ecosystem services and indicators. UNEP-WCMC, LWEC, UK

Delaine M., Bernard N., Gilbert D., Recourt P., du Châtelet E. A. (2017) Origin and diversity of testate amoebae shell composition: Example of Bullinularia indica living in Sphagnum capillifolium. Eur. J. Protistol. 59: 14-25

Dray S., Legendre P. (2008) Testing the species traits-environment relationships: the fourth-corner problem revisited. Ecology 89: 3400-3412

Fournier B., Lara E., Jassey V. E. J., Mitchell E. A. D. (2015) Functional traits as a new approach for interpreting testate amoeba palaeo-records in peatlands and assessing the causes and consequences of past changes in species composition. The Holocene 25: $1375-1383$

Fournier B., Malysheva E., Mazei Y., Moretti M., Mitchell E. A. D. (2012) Toward the use of testate amoeba functional traits as indicator of floodplain restoration success. Eur. J. Soil Biol. 49: 85-91

Gilbert D., Amblard C., Bourdier G., Francez A. J. (1998) The microbial loop at the surface of a peatland: structure, function, and impact of nutrient input. Microb. Ecol. 35: 83-93

Gilbert D., Mitchell E. A. D. (2006) Microbial diversity in Sphagnum peatlands. Dev. Earth Surf. Process 9: 287-318

Gilbert D., Mitchell E. A. D., Amblard C., Bourdier G., Francez A. J. (2003) Population dynamics and food preferences of the testate amoeba Nebela tincta major-bohemica-collaris complex (Protozoa) in a Sphagnum peatland. Acta Protozool. 42: 99-104

Gomaa F., Kosakyan A., Heger T. J., Corsaro D., Mitchell E. A. D., Lara E. (2014) One alga to rule them all: unrelated mixotrophic testate amoebae (Amoebozoa, Rhizaria and Stramenopiles) share the same symbiont (Trebouxiophyceae). Protist 165: $161-176$

Gomaa F., Mitchell E. A. D., Lara E. (2013) Amphitremida (Poche, 1913 ) is a new major, ubiquitous Labyrinthulomycete clade. PLOS ONE 8: e53046

Gower J. C. (1971) A general coefficient of similarity and some of its properties. Biometrics 27: 857-871

Graf U., Kuchler M., Ecker K., Feldmeyer-Christe E., Könitzer C., Känzig U., Grosvernier P., Berchten F., Lugon A., David R., Marti F. (2007) Etat et évolution des marais en Suisse. Office Fédéral de l'Environnement, Berne

Grosvernier P., Matthey Y., Buttler A. (1997) Growth potential of three Sphagnum species in relation to water table level and peat properties with implications for their restoration in cut-over bogs. J. Appl. Ecol. 34: 471-483

Heal O. W. (1964) Observations on the seasonal and spatial distribution of testacea (Protozoa: Rhizopoda) in Sphagnum. J. Anim. Ecol. 33: 395-412

Heger T. J., Mitchell E. A. D., Leander B. S. (2013) Holarctic phylogeography of the testate amoeba Hyalosphenia papilio (Amoebozoa: Arcellinida) reveals extensive genetic diversity explained more by environment than dispersal limitation. Mol. Ecol. 22: 5172-5184

Heger T. J., Mitchell E. A. D., Ledeganck P., Vincke S., Van de Vijver B., Beyens L. (2009) The curse of taxonomic uncertainty in biogeographical studies of free-living terrestrial protists: a case study of testate amoebae from Amsterdam Island. J. Biogeogr. 36: $1551-1560$

Holt R. D. (2009) Bringing the Hutchinsonian niche into the 21st century: Ecological and evolutionary perspectives. Proc. Natl. Acad. Sci. USA 106: 19659-19665 
Jassey V. E. J., Chiapusio G., Mitchell E. A. D., Binet P., Toussaint M.-L., Gilbert D. (2011) Fine-scale horizontal and vertical micro-distribution patterns of testate amoebae along a narrow fen/ bog gradient. Microb. Ecol. 61: 374-385

Jassey V. E. J., Meyer C., Dupuy C., Bernard N., Mitchell E. A. D., Toussaint M.-L., Metian M., Chatelain A. P., Gilbert D. (2013a) To what extent do food preferences explain the trophic position of heterotrophic and mixotrophic microbial consumers in a Sphagnum peatland? Microb. Ecol. 66: 571-580

Jassey V. E. J., Chiapusio G., Binet P., Buttler A., Laggoun-Defarge F., Delarue F., Bernard N., Mitchell E. A. D., Toussaint M. L., Francez A. J., Gilbert D. (2013b) Above- and belowground linkages in Sphagnum peatland: climate warming affects plantmicrobial interactions. Glob. Change Biol. 19: 811-823

Jassey V. E. J., Signarbieux C., Hättenschwiler S., Bragazza L., Buttler A., Delarue F., Fournier B., Gilbert D., Laggoun-Défarge F., Lara E., Mills R. T. E., Mitchell E. A. D., Payne R. J., Robroek B. J. M. (2015) An unexpected role for mixotrophs in the response of peatland carbon cycling to climate warming. Sci. Rep. 5: 16931

Juggins, S. (2015) rioja: Analysis of Quaternary Science Data, R package

Kaiser H. F. (1991) Coefficient Alpha for a Principal Component and the Kaiser-Guttman Rule. Psychol. Rep. 68: 855-858

Kajukało K., Fiałkiewicz-Kozieł B., Gałka M., Kołaczek P., Lamentowicz M. (2016) Abrupt ecological changes in the last 800 years inferred from a mountainous bog using testate amoebae traits and multi-proxy data. Eur. J. Protistol. 55: 165-180

Kearney M., Simpson S. J., Raubenheimer D., Helmuth B. (2010) Modelling the ecological niche from functional traits. Philos. Trans. R. Soc. B. Biol. Sci. 365: 3469-3483

Kembel S. W., Cowan P. D., Helmus M. R., Cornwell W. K., Morlon H., Ackerly D. D., Blomberg S. P., Webb C. O. (2010) Picante: $\mathrm{R}$ tools for integrating phylogenies and ecology. Bioinformatics 26: $1463-1464$

Koenig I., Mulot M., Mitchell E. A. D. (2018) Taxonomic and functional traits responses of Sphagnum peatland testate amoebae to experimentally manipulated water table. Ecol. Indic.

Kosakyan A., Gomaa F., Mitchell E. A. D., Heger T. J., Lara E. (2013) Using DNA-barcoding for sorting out protist species complexes: A case study of the Nebela tincta-collaris-bohemica group (Amoebozoa; Arcellinida, Hyalospheniidae). Eur. J. Protistol. 49: 222-37

Kosakyan A., Lahr D. J. G., Mulot M., Meisterfeld R., Mitchell E. A. D., Lara E. (2016) Phylogenetic reconstruction based on COI reshuffles the taxonomy of Hyalosphenid shelled (testate) amoebae and reveals the convoluted evolution of shell plate shapes. Cladistics. 32 (6): 606-623

Laggoun-Defarge F., Mitchell E. A. D., Gilbert D., Disnar J.-R., Comont L., Warner B. G., Buttler A. (2008) Cut-over peatland regeneration assessment using organic matter and microbial indicators (bacteria and testate amoebae). J. Appl. Ecol. 45: 716-727

Lahr D. J. G., Bosak T., Lara E., Mitchell E. A. D. (2015) The Phanerozoic diversification of silica-cycling testate amoebae and its possible links to changes in terrestrial ecosystems. PeerJ. 3: 1234

Laliberté E., Legendre P., Shipley, B. (2014) FD: measuring functional diversity from multiple traits, and other tools for functional ecology. R package

Lamentowicz L., Gabka M., Rusinska A., Sobczynski T., Owsianny P. M., Lamentowicz M. (2011) Testate amoeba (Arcellinida, Eu- glyphida) ecology along a poor-rich gradient in fens of Western Poland. Int. Rev. Hydrobiol. 96: 356-380

Lamentowicz M., Gałka M., Lamentowicz Ł., Obremska M., Kühl N., Lücke A., Jassey V. E. J. (2015) Reconstructing climate change and ombrotrophic bog development during the last 4000 years in northern Poland using biotic proxies, stable isotopes and trait-based approach. Palaeogeogr. Palaeoclimatol. Palaeoecol. 418: 261-277

Lamentowicz Ł., Lamentowicz M., Gabka M. (2008) Testate amoebae ecology and a local transfer function from a peatland in western Poland. Wetlands 28: 164-175

Lamentowicz M., Mitchell E. A. D. (2005) The ecology of testate amoebae (protists) in Sphagnum in north-western Poland in relation to peatland ecology. Microb. Ecol. 50: 48-63

Lara E., Heger T. J., Mitchell E. A. D., Meisterfeld R., Ekelund F. (2007) SSU rRNA reveals a sequential increase in shell complexity among the euglyphid testate amoebae (Rhizaria : Euglyphida). Protist 158: 229-237

Lavorel S., Garnier E. (2002) Predicting changes in community composition and ecosystem functioning from plant traits: revisiting the Holy Grail. Funct. Ecol. 16: 545-556

Legendre P., Gallagher E. D. (2001) Ecologically meaningful transformations for ordination of species data. Oecologia 129: 271-280

Lizoňová Z., Horsák M. (2017) Contrasting diversity of testate amoebae communities in Sphagnum and brown-moss dominated patches in relation to shell counts. Eur. J. Protistol. 58: 135-142

MacArthur R. H. (1957) On the relative abundance of bird species. Proc. Natl. Acad. Sci. 43: 293-295

Makarieva A. M., Gorshkov V. G., Li B.-L., Chown S. L., Reich P. B., Gavrilov V. M. (2008) Mean mass-specific metabolic rates are strikingly similar across life's major domains: evidence for life's metabolic optimum. Proc. Natl. Acad. Sci. 105: 16994-16999

Marcisz K., Colombaroli D., Jassey V. E. J., Tinner W., Kołaczek P., Gałka M., Karpińska-Kołaczek M., Słowiński M., Lamentowicz M. (2016) A novel testate amoebae trait-based approach to infer environmental disturbance in Sphagnum peatlands. Sci. Rep. 6

Marcisz K., Lamentowicz Ł., Słowińska S., Słowiński M., Muszak W., Lamentowicz M. (2014) Seasonal changes in Sphagnum peatland testate amoeba communities along a hydrological gradient. Eur. J. Protistol. 50: 445-455

Mason N. W., Lanoiselée C., Mouillot D., Wilson J. B., Argillier C. (2008) Does niche overlap control relative abundance in French lacustrine fish communities? A new method incorporating functional traits. J. Anim. Ecol. 77: 661-669

Mazei Y. A., Tsyganov A. N., Bubnova O. A. (2009) The species composition and community structure of testate amoebae in Sphagnum bogs of northern Karelia (The White Sea Lowland). Zool. Zhurnal. 88: 771-782

Messier J., McGill B. J., Lechowicz M. J. (2010) How do traits vary across ecological scales? A case for trait-based ecology. Ecol. Lett. 13: 838-848

Millenium Ecosystem Assessment, MEA (2005) Ecosystems and human well-being. The Island Press, Washington D.C.

Mitchell E. A. D. (2003) The identification of Nebela and similar species with indications on their ecology and distribution. Univ. Anchorage Alsk

Mitchell E. A. D., Buttler A. J., Warner B. G., Gobat J.-M. (1999) Ecology of testate amoebae (Protozoa : Rhizopoda) in Sphag- 
num peatlands in the Jura Mountains, Switzerland and France. Ecoscience 6: 565-576

Mitchell E. A. D., Charman D. J. G., Warner B. G. (2008) Testate amoebae analysis in ecological and paleoecological studies of wetlands: past, present and future. Biodivers. Conserv. 17: 2115-2137

Mitchell E. A. D., Lamentowicz M., Payne R. J., Mazei Y. (2014) Effect of taxonomic resolution on ecological and palaeoecological inference - a test using testate amoeba water table depth transfer functions. Quat. Sci. Rev. 91: 62-69

Mlambo M. C. (2014) Not all traits are 'functional': insights from taxonomy and biodiversity-ecosystem functioning research. Biodivers. Conserv. 23: 781-790

Mouillot D., Dumay O., Tomasini J. A. (2007) Limiting similarity, niche filtering and functional diversity in coastal lagoon fish communities. Estuar. Coast. Shelf. Sci. 71: 443-456

Mulot M., Marcisz K., Grandgirard L., Lara E., Kosakyan A., Robroek B. J., Lamentowicz M., Payne R. J., Mitchell E. A. D. (2017) Genetic determinism vs. phenotypic plasticity in protist morphology. J. Eukaryot. Microbiol.

Mulot M., Varidel, D., Mitchell, E. A. D. (2015) A mesocosm approach to study the response of Sphagnum peatlands to hydrological changes: setup, optimisation and performance. Mires Peat 16: 1-12

Niemi G. J., McDonald M. E. (2004) Application of ecological indicators. Annu. Rev. Ecol. Evol. Syst. 35: 89-111

Norris K., Bailey M., Keith A., Maskell L., Reading C., Turner S., Vanbergen A., Watt A., and others (2011) Biodiversity in the context of ecosystem services. Chapter 4 in: Technical Report. UK National Ecosystem Assessment, 63-103

Ogden G. G., Hedley R. H. (1980) An atlas of freshwater testate amoebae. Soil Sci. 130: 176

Oksanen J. (2015) Vegan: an introduction to ordination. R package.

Oliverio A. M., Lahr D. J. G., Nguyen T., Katz L. A. (2014) Cryptic diversity within morphospecies of testate amoebae (Amoebozoa: Arcellinida) in New England bogs and fens. Protist 165: 196-207

Opravilova V., Hajek M. (2006) The variation of testacean assemblages (Rhizopoda) along the complete base-richness gradient in fens: A case study from the Western Carpathians. Acta Protozool. 45: 191-204

Payne R. J. (2013) Seven reasons why protists make useful bioindicators. Acta Protozool. 52: 105

Payne R. J., Charman D. J., Matthews S., Eastwood W. J. (2008) Testate amoebae as palaeohydrological proxies in Surmene Agacbasi Yaylasi peatland (Northeast Turkey). Wetlands 28: 311-323

Payne R. J., Creevy A., Malysheva E., Ratcliffe J., Andersen R., Tsyganov A. N., Rowson J. G., Marcisz K., Zielińska M., Lamentowicz M., Lapshina E. D., Mazei Y. (2016) Tree encroachment may lead to functionally-significant changes in peatland testate amoeba communities. Soil Biol. Biochem. 98: 18-21

Pinto R., de Jonge V. N., Marques J. C. (2014) Linking biodiversity indicators, ecosystem functioning, provision of services and human well-being in estuarine systems: Application of a conceptual framework. Ecol. Indic. 36: 644-655

Podani J. (1999) Extending Gower's general coefficient of similarity to ordinal characters. Taxon 331-340

Qin Y., Mitchell E. A. D., Lamentowicz M., Payne R. J., Lara E., Gu Y., Huang X., Wang H. (2013) Ecology of testate amoebae in peatlands of central China and development of a transfer function for paleohydrological reconstruction. J. Paleolimnol. 50: 319-330

R Core Team (2016) R: A language and environment for statistical computing. R Foundation for Statistical Computing, Vienna, Austria

Ricotta C., Moretti M. (2011) CWM and Rao's quadratic diversity: a unified framework for functional ecology. Oecologia 167: 181-188

Schwind L. T. F., Arrieira R. L., Bonecker C. C., Lansa-Tôha F. A., Amodêo F. (2016) Chlorophyll-a and suspended inorganic material affecting the shell traits of testate amoebae community. Acta Protozool. 55 (3): 145-154

Singer D., Kosakyan A., Pillonel A., Mitchell E. A. D., Lara E. (2015) Eight species in the Nebela collaris complex: Nebela gimlii (Arcellinida, Hyalospheniidae), a new species described from a Swiss raised bog. Eur. J. Protistol. 51: 79-85

Tsyganov A. N., Aerts R., Nijs I., Cornelissen J. H. C., Beyens L. (2012) Sphagnum-dwelling testate amoebae in subarctic bogs are more sensitive to soil warming in the growing season than in winter: The results of eight-year field climate manipulations. Protist 163: 400-414

Turner T. E., Swindles G. T., Charman D. J., Blundell A. (2013) Comparing regional and supra-regional transfer functions for palaeohydrological reconstruction from Holocene peatlands. Palaeogeogr. Palaeoclimatol. Palaeoecol. 369: 395-408

Villéger S., Mason N. W., Mouillot D. (2008) New multidimensional functional diversity indices for a multifaceted framework in functional ecology. Ecology 89: 2290-2301

Violle C., Navas M.-L., Vile D., Kazakou E., Fortunel C., Hummel I., Garnier E. (2007) Let the concept of trait be functional! Oikos 116: 882-892

Webb C. O., Losos J. B., Agrawal A. A. (2006) Integrating phylogenies into community ecology. Ecology 87: S1-S2

Wilkinson D. M., Mitchell E. A. D. (2010) Testate amoebae and nutrient cycling with particular reference to soils. Geomicrobiol. J. 27: $520-533$

Received on $2^{\text {nd }}$ May, 2017; revised on $23^{\text {rd }}$ October; 2017; accepted on $23^{\text {rd }}$ October; 2017 
Supp. Table 1. Whole dataset of testate amoeba.

\begin{tabular}{|c|c|c|c|c|c|c|c|c|c|c|c|c|c|c|c|c|c|c|c|}
\hline Site & Date & Time & Treatment & mp_wri|A & Arc_cat & Arc_fla & Ass_mus & Cen_acu & Cor_dub & Cry_ovi & Cyc_eur & Eug_cil & Hel_ros & Hel_sph & ya_pap & Neb_tin & Phr_acr & hy_gri & tal Ind. \\
\hline D1 & 2012-08-02 & TO & Dry & $0,0 \%$ & $8,4 \%$ & $0,8 \%$ & $0,0 \%$ & $0,0 \%$ & $0,0 \%$ & $0,0 \%$ & $0,0 \%$ & $2,3 \%$ & $0,8 \%$ & $0,0 \%$ & $85,5 \%$ & $2,3 \%$ & $0,0 \%$ & $0,0 \%$ & 131 \\
\hline D2 & $2012-08-02$ & T0 & Dry & $0,0 \%$ & $0,0 \%$ & $5,6 \%$ & $\%$ & $0,8 \%$ & $0,0 \%$ & $0,0 \%$ & $0,0 \%$ & $0,0 \%$ & $6 \%$ & $0,0 \%$ & $0,4 \%$ & $1,6 \%$ & $0,0 \%$ & $0 \%$ & 71 \\
\hline D3 & $12-08-02$ & TO & Dry & $\%$ & $7,4 \%$ & \begin{tabular}{|l|}
$16,7 \%$ \\
\end{tabular} & t & $\% \%$ & $\%$ & $\%$ & $\%$ & $3,7 \%$ & $9 \%$ & $\%$ & $3 \%$ & $8,3 \%$ & $0,0 \%$ & $0 \%$ & 0 \\
\hline D4 & $012-08-02$ & TO & ry & $0,0 \%$ & $9,5 \%$ & $0,0 \%$ & $\%$ & $0,0 \%$ & $0,0 \%$ & $0,0 \%$ & $0,0 \%$ & $3,2 \%$ & $0,0 \%$ & $0,0 \%$ & , 3\% & $0,0 \%$ & $0,0 \%$ &, $0 \%$ & $6=$ \\
\hline D5 & $2012-08-02$ & T0 & Dry & $0,0 \%$ & $1,2 \%$ & $0,0 \%$ & $\%$ & $0,0 \%$ & $3,5 \%$ & $0 \%$ & $0,0 \%$ & $0,0 \%$ & $0,0 \%$ &, $0 \%$ & $5,9 \%$ & $9,4 \%$ & $0,0 \%$ & $0 \%$ & \\
\hline 11 & 2012-08-02 & TO & \begin{tabular}{|l|} 
Intermediate \\
\end{tabular} & $0 \%$ & $9,8 \%$ & $0,0 \%$ & $\%$ & $\%$ & $1,0 \%$ & $0,0 \%$ & $\%$ & $0,0 \%$ & $0 \%$ & $0 \%$ & $0 \%$ & $4,6 \%$ & $0,0 \%$ & $0 \%$ & 194 \\
\hline 12 & 2012-08-02 & TO & Intermediate & $0,0 \%$ & $1,6 \%$ & $0,0 \%$ & $\%$ & $0,3 \%$ & $0,0 \%$ & $0,0 \%$ & $0 \%$ & $0,0 \%$ & $0,0 \%$ & $0,0 \%$ &, $9 \%$ & $1,3 \%$ & $0,0 \%$ & $0 \%$ & 2 \\
\hline 13 & 2012-08-02 & TO & Interme & $0,0 \%$ & $1,8 \%$ & $0,0 \%$ & $1,2 \%$ & $1,2 \%$ & $0,0 \%$ & $0,0 \%$ & $0,0 \%$ & $0,0 \%$ & $0,0 \%$ & $0,0 \%$ & $0,9 \%$ & $4,8 \%$ & $0,0 \%$ &, $0 \%$ & 165 \\
\hline 14 & 2012-08-02 & T0 & Interm & $0,0 \%$ & $11,1 \%$ & $0,0 \%$ & $5 \%$ & $1,0 \%$ & $0,0 \%$ & $0,0 \%$ & $0,5 \%$ & $0,5 \%$ & $0,0 \%$ & $0 \%$ & ,9\% & $3,5 \%$ & $0,0 \%$ & $0 \%$ & 195 \\
\hline 15 & $2012-08-02$ & TO & Intermediate & $0,0 \%$ & $8,5 \%$ & $0,0 \%$ & $\%$ & $1,2 \%$ & $0,0 \%$ & $0,0 \%$ & $\%$ & $0,0 \%$ & $2,4 \%$ & $\%$ & $3 \%$ & $3,7 \%$ & $0,0 \%$ & $0 \%$ & \\
\hline W1 & 2012-08-02 & TO & Wet & $0,0 \%$ & $2,7 \%$ & $6,1 \%$ & $2,7 \%$ & $0,7 \%$ & $0,0 \%$ & $0,0 \%$ & $0,0 \%$ & $2,0 \%$ & $0,7 \%$ & $0,0 \%$ & $3,8 \%$ & $1,4 \%$ & $0,0 \%$ & $0,0 \%$ & $14 \varepsilon$ \\
\hline $\mathrm{W} 2$ & 2012-08-02 & T0 & Wet & $0,0 \%$ & $3,6 \%$ & $11,5 \%$ & $0,0 \%$ & $0,6 \%$ & $0,0 \%$ & $0,0 \%$ & $0,6 \%$ & $2,4 \%$ & $0,6 \%$ & $0,0 \%$ & $9,4 \%$ & $1,2 \%$ & $0,0 \%$ &, $0 \%$ & \\
\hline W3 & 2012-08-02 & TO & Wet & $0 \%$ & $8,6 \%$ & $5,7 \%$ & $\%$ & $2,9 \%$ & $0,0 \%$ & $0,0 \%$ & $4 \%$ & $2,9 \%$ & $0,0 \%$ &, $0 \%$ & $1,3 \%$ & $4,3 \%$ & $0,0 \%$ &, $0 \%$ & 70 \\
\hline W4 & 2012 & TO & Wet & 0,0 & $0,0 \%$ & $0,0 \%$ & $0,0 \%$ & $0,0 \%$ & $0,0 \%$ & $0 \%$ & $7 \%$ & $0,0 \%$ & $4,4 \%$ & (1) & $2 \%$ & $0,7 \%$ & $0,0 \%$ & $0 \%$ & 13 \\
\hline W5 & 2012-08-02 & TO & let & $0,0 \%$ & $2,8 \%$ & $0,0 \%$ & $0,6 \%$ & $0,0 \%$ & $0,0 \%$ & $0,0 \%$ & $0,0 \%$ & $1,1 \%$ & $0,6 \%$ & $0,0 \%$ & $3,3 \%$ & $1,7 \%$ & $0,0 \%$ & $0,0 \%$ & 180 \\
\hline D1 & 2014 & D1 & ry & $0,0 \%$ & $3,4 \%$ & $0,0 \%$ & $t$ & $7,4 \%$ & $0,0 \%$ & $0,0 \%$ & $\%$ & $2,7 \%$ & $26,2 \%$ & 0\% & $2 \%$ & $28,2 \%$ & $0,0 \%$ &, $7 \%$ & 149 \\
\hline D2 & 2014 & D1 & ry & 0,0 & $4,3 \%$ & $0,0 \%$ & & $2,1 \%$ & $17,0 \%$ & $0,0 \%$ & $\%$ & $10,6 \%$ & $2,1 \%$ & 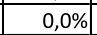 & $7,0 \%$ & $2,6 \%$ & $0,0 \%$ & $0 \%$ & \\
\hline D3 & 2014-03-27 & D1 & Dry & 0,0 & $1,1 \%$ & $0,0 \%$ & $\%$ & $0,0 \%$ & $83,9 \%$ & $0,0 \%$ & $0,0 \%$ & $0,6 \%$ & $0,6 \%$ & $0,0 \%$ & $0,6 \%$ & $2,6 \%$ & $0,0 \%$ & $0 \%$ & 174 \\
\hline D4 & 2014-03-27 & D1 & ry & $0,0 \%$ & $0,0 \%$ & $0,0 \%$ & \% & $27,6 \%$ & $6,9 \%$ & $0,0 \%$ & $0 \%$ & $0,0 \%$ & $17,2 \%$ & $0,0 \%$ & $34,5 \%$ & $0,3 \%$ & $0,0 \%$ &, $0 \%$ & \\
\hline D5 & 2014 & D1 & ry & $0,0 \%$ & $0,5 \%$ & $0,0 \%$ & $\%$ & $1,5 \%$ & $1,9 \%$ & $0 \%$ & $\%$ & $8,4 \%$ & $0,0 \%$ & $0 \%$ & $4 \%$ & $7,3 \%$ & $0,0 \%$ & ,0\% & 202 \\
\hline 11 & 2014 & D1 & ate & 0,0 & $5,3 \%$ & $0,0 \%$ & & $0,0 \%$ & $0,0 \%$ & $0 \%$ & $\%$ & $0,9 \%$ & $0,0 \%$ & & $3 \%$ & $0,9 \%$ & $6,1 \%$ & $0,9 \%$ & 11 \\
\hline 12 & 2014-03-27 & D1 & ate & $0,0 \%$ & $7 \%$ & $0 \%$ & & & $0,0 \%$ & $0 \%$ & $\%$ & $0,6 \%$ & $2 \%$ & $\%$ & $1 \%$ & $0 \%$ & $6,9 \%$ & $0 \%$ & 17 \\
\hline 13 & 2014-03-27 & D1 & tern & $0,0 \%$ & $10,2 \%$ & $0,0 \%$ & t & $0,5 \%$ & $0,0 \%$ & $0,0 \%$ & $\%$ & $0,0 \%$ & $2 \%$ & \% & $4 \%$ & $7 \%$ & $0,0 \%$ & $0,0 \%$ & 18 \\
\hline 14 & $2014-03-27$ & D1 & Interm & $0,0 \%$ & $4,1 \%$ & $0,0 \%$ & & $0,0 \%$ & $0,0 \%$ & $0,0 \%$ & + & $0,0 \%$ & 6 & $0,0 \%$ & $8 \%$ & $2,7 \%$ & $0,0 \%$ & $0,0 \%$ & \\
\hline 15 & 2014-03-27 & D1 & tern & 0,0 & $7,4 \%$ & $0,0 \%$ & $1,2 \%$ & $1,2 \%$ & $0,0 \%$ & $0,0 \%$ & $\%$ & $1,2 \%$ & $0 \%$ & 0, & $2 \%$ & $3,7 \%$ & $0,0 \%$ & $0 \%$ & 8 \\
\hline W1 & 2014 & D1 & et & $1,6 \%$ & $0,0 \%$ & $0,0 \%$ & 6 & $0,0 \%$ & $0,0 \%$ & $0 \%$ & $\%$ & $0,0 \%$ & $2 \%$ & $0 \%$ & $1 \%$ & $6 \%$ & $9,5 \%$ & $0 \%$ & \\
\hline W2 & 2014 & D1 & et & $3,6 \%$ & $3,6 \%$ & $0,0 \%$ & $t$ & $0,0 \%$ & $0,0 \%$ & $0 \%$ & $\%$ & $0,0 \%$ & $0 \%$ & $0 \%$ & , ,0\%| &, $0 \%$ & \begin{tabular}{|c|}
$6,9 \%$ \\
\end{tabular} &, $0 \%$ & \\
\hline W3 & 2014 & D1 & et & 2,6 & 0,0 & $0,0 \%$ & & $0,0 \%$ & $0,0 \%$ & $0,0 \%$ & $0,0 \%$ & $0,0 \%$ & 6 & $0,0 \%$ & $4 \%$ &, $0 \%$ & $3,9 \%$ & $0 \%$ & \\
\hline W4 & 2014 & D1 & et & 39 & $0,0 \%$ & $0,0 \%$ & & & $0,0 \%$ & $0 \%$ & $\%$ & $2,0 \%$ & 6 & & की & $\%$ & $5,9 \%$ & $0 \%$ & \\
\hline W5 & $2014-03-27$ & D1 & Wet & $3,6 \%$ & $1,8 \%$ & $0,0 \%$ & \%क & $\%$ & $0,0 \%$ & $0,0 \%$ & $\%$ & $0,0 \%$ & $8 \%$ & $0 \%$ & $1,1 \%$ &, $0 \%$ & $0,0 \%$ & $0,0 \%$ & 112 \\
\hline D1 & $2015-$ & R1 & Dry & 0,0 & $0,9 \%$ & $0,0 \%$ & $1,8 \%$ & $1,8 \%$ & $32,9 \%$ & $4,7 \%$ & + & $5,0 \%$ & 89 & $0,9 \%$ & $12,6 \%$ & $2,3 \%$ & $0,0 \%$ & $5,4 \%$ & 22 \\
\hline D2 & 2015 & R1 & D & $0,0 \%$ & 4,6 & $0,0 \%$ & & $\%$ & $4,9 \%$ & $8 \%$ & $\%$ & $2,0 \%$ & $0 \%$ & & $3 \%$ & $34,9 \%$ & $0,0 \%$ & $7 \%$ & 15 \\
\hline D3 & 2015 & R1 & $y$ & & & 0, & & & $7 \%$ & $29,5 \%$ & & $2,6 \%$ & & & $9 \%$ & & $0,0 \%$ & $0 \%$ & 15 \\
\hline D4 & 2015 & R1 & Dry & 0,0 & 0,0 & 0,0 & & & $0,8 \%$ & $4,1 \%$ & $7 \%$ & $11,5 \%$ & \% &, $0 \%$ & $3,9 \%$ & $8,5 \%$ & $0,0 \%$ & $0 \%$ & 12 \\
\hline D5 & 2015-05-18 & R1 & D & 0,0 & 0,0 & $0,0 \%$ & 0,0 & $1,8 \%$ & $59,6 \%$ & $11,9 \%$ & $0,0 \%$ & $0,9 \%$ & 3,79 & $0, \mathrm{c}$ & $4,6 \%$ & $17,4 \%$ & $0,0 \%$ & , 0\% & 10 \\
\hline 11 & 2015 & R1 & err & $0,0^{\circ}$ & 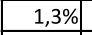 & $0,0 \%$ & & $0,0 \%$ & $0,0 \%$ & $0,0 \%$ & $\%$ & $0,7 \%$ & 6 & & $4 \%$ & $0,0 \%$ & $7,8 \%$ & $0 \%$ & 13 \\
\hline 12 & 2015 & R1 & $\mathrm{orn}$ & & $1,1 \%$ & $0,0 \%$ & 1 & & of & $\%$ & 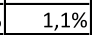 & $0 \%$ & 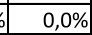 & & $2 \%$ & $0 \%$ & $16,6 \%$ & $0 \%$ & 18 \\
\hline 13 & 2015 & R1 & Interm & 0,0 & 0,8 & $0,0 \%$ & & 0 & $0,3 \%$ & $0 \%$ & $0,0 \%$ &, $0 \%$ & 6. & 28. & $1,3 \%$ & $7 \%$ & $0,8 \%$ & $0 \%$ & 11 \\
\hline 14 & $2015-05-18$ & R1 & Intern & 0.0 & $07 \%$ & $3 \%$ & 70] & & $0,7 \%$ & $0 \%$ & $\%$ & $0,0 \%$ & $0 \%$ & & $5 \%$ & $0 \%$ & $0,7 \%$ & $0 \%$ & 15 \\
\hline 15 & 2015 & R1 & 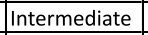 & & & $0,0 \%$ & & & & & & & 6 & & & $\%$ & $0,6 \%$ & $0 \%$ & 15 \\
\hline W1 & $2015-05-18$ & R1 & Wet & 0 & 1,3 & $0,0 \%$ & & $\%$ & $4,4 \%$ & $0,0 \%$ & 0, & $0,0 \%$ & 6 & & $8 \%$ & $0 \%$ & $13,7 \%$ & $0 \%$ & 22 \\
\hline W2 & 2015-05-18 & R1 & Wet & 19 & 5,6 & $0,0 \%$ & & $5,6 \%$ & $1,1 \%$ & $0 \%$ & is & $0,0 \%$ & 6 & $5,6 \%$ & $2,2 \%$ &, $6 \%$ & $3,3 \%$ & $0 \%$ & 18 \\
\hline W3 & 2015 & R1 & Wet & & 0,0 & $0,0 \%$ & & & $2,0 \%$ & $0 \%$ & $\%$ & $0,0 \%$ & $0 \%$ & $0 \%$ & $1 \%$ & $\%$ & $0,5 \%$ & $0 \%$ & 20 \\
\hline W4 & 8 & $R$ & n & & & & & & & & & & & & & & $10,3 \%$ & $0 \%$ & 14 \\
\hline \begin{tabular}{|l|} 
W5 \\
\end{tabular} & 2015 & R1 & et & & & $0,0 \%$ & & & & $0 \%$ & & 2,0 & 6. & & & $\%$ & $5,3 \%$ & $0,0 \%$ & 715 \\
\hline D1 & $2015-09-24$ & R2 & Dry & & -1 & $0 \%$ & & $\%$ & $7 \%$ & $0 \%$ & $5 \%$ & $4,2 \%$ & $8,4 \%$ & $7 \%$ & ,9\% &, $2 \%$ & $1,7 \%$ & $15,1 \%$ & 11 \\
\hline D2 & $2015-09-24$ & R2 & Dry & & 0,0 & $0,0 \%$ & & $\%$ & $9,6 \%$ & $0,0 \%$ & $\%$ & $0,9 \%$ & $21,1 \%$ & & $7 \%$ & $1,1 \%$ & $0,9 \%$ & $5,3 \%$ & 11 \\
\hline D3 & $2015-$ & R2 & D & & 1, & & & & & & & 68. & \begin{tabular}{|l|l|}
6 & 18,2 \\
\end{tabular} & & t & & $0 \%$ & $20,5 \%$ & \\
\hline D4 & $2015-$ & R2 & y & & & $0,0 \%$ & & & & $0 \%$ & $40,7 \%$ & 6,7 & 89 & & $9 \%$ & $8 \%$ & $0 \%$ & $4,4 \%$ & 13 \\
\hline D5 & $2015-09-24$ & R2 & Dry & $0,0 \%$ & 0,9 & $0,0 \%$ &, $9 \%$ & $\%$ & 6,0 & $0 \%$ & $\%$ & $8,6 \%$ & $6 \%$ & & $3 \%$ & $17,2 \%$ & $0,9 \%$ & $0 \%$ & 11 \\
\hline 11 & 2015 & R2 & & & & $0,0 \%$ & & & & & & $0,0 \%$ & 0 & & & $\%$ & $10,3 \%$ & $0 \%$ & 13 \\
\hline 12 & $2015-09-24$ & R2 & In & & & 8\% & 2 & & & $0 \%$ & & $0,0 \%$ & & & of & $\%$ & $17,2 \%$ & $0 \%$ & 14 \\
\hline 13 & $2015-09-24$ & R2 & Interm & 0,8 & $0,8 \%$ & $0,0 \%$ & $0 \%$ & $23,0 \%$ & $4,0 \%$ & $0,0 \%$ & $3 \%$ & $1,6 \%$ & $3 \%$ & $0 \%$ & $1 \%$ & $19,0 \%$ & $0,8 \%$ & $8 \%$ & 6 \\
\hline 14 & $2015-09-24$ & R2 & Intern & $0,0 \%$ & 3,6 & $5,8 \%$ &, $9 \%$ & & $0,0 \%$ & $0,0 \%$ & $\%$ & $0,0 \%$ & $0 \%$ & & & $1,4 \%$ & $0,7 \%$ & $0 \%$ & 13 \\
\hline 15 & $2015-09-24$ & R2 & Interm & 0,0 & $5,6 \%$ & $0, \mathrm{c}$ & & & $0, \mathrm{C}$ & & & 0,6 & & & & &, $0 \%$ & $\%$ & 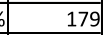 \\
\hline W1 & $2015-09-24$ & R2 & Wet & & & & & & & & & & & & & & $13,4 \%$ & $0 \%$ & \\
\hline W2 & $2015-09-24$ & R2 & Wet & $2,8 \%$ & $2,8 \%$ & 0,0 & $\%$ & $33,6 \%$ & $0,9 \%$ & $0,0 \%$ & $\%$ & $15,0 \%$ & $5 \%$ & $0,0 \%$ & $4 \%$ & $6,5 \%$ & $1,9 \%$ & $7 \%$ & 6 \\
\hline W3 & $15-09-24$ & R2 & Wet & 0 & 1,9 & 0,0 & & & $0,0 \%$ & 0 & & $2,8 \%$ & 6 & & &, $0 \%$ & $34,3 \%$ & $0 \%$ & 6 \\
\hline W4 & $2015-09-24$ & R2 & Wet & 0,0 & 0,0 & 0,79 & & & $9,5 \%$ & 0,0 & & $2,9 \%$ & 0,0 & & $10,9 \%$ & $0,0 \%$ & $3,6 \%$ &, $0 \%$ & 13 \\
\hline W5 & $2015-09-24$ & R2 & Wet & $0,0 \%$ & $0,0 \%$ & $0,0 \%$ & $46,0 \%$ & $2,2 \%$ & $11,7 \%$ & $0,0 \%$ & $0,0 \%$ & $8,0 \%$ & $3,6 \%$ & $0,0 \%$ & $7,3 \%$ & $16,8 \%$ & $2,9 \%$ & $1,5 \%$ & \\
\hline
\end{tabular}


208 I. Koenig et al.

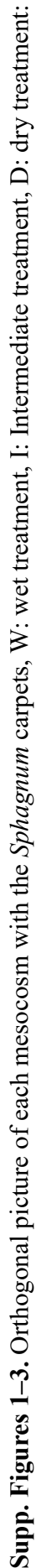
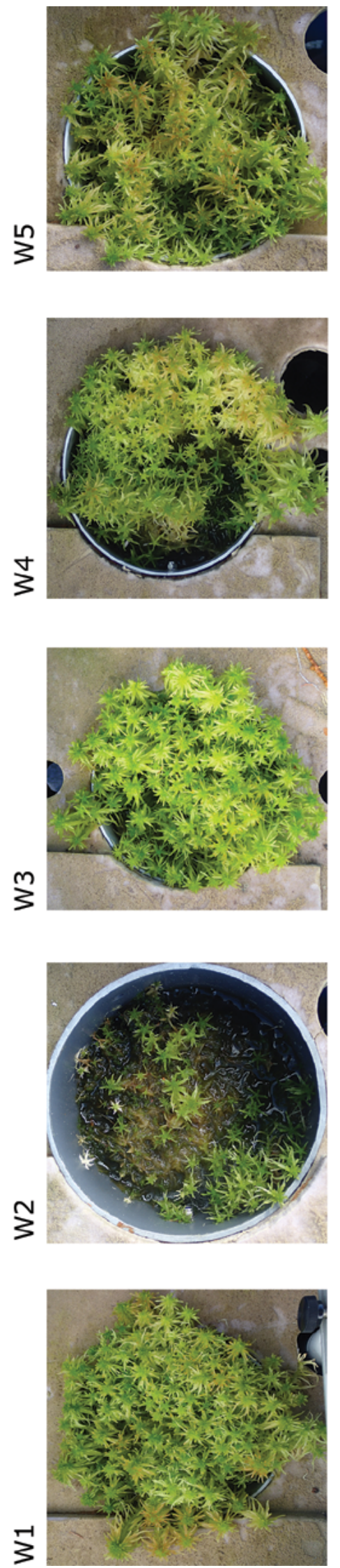
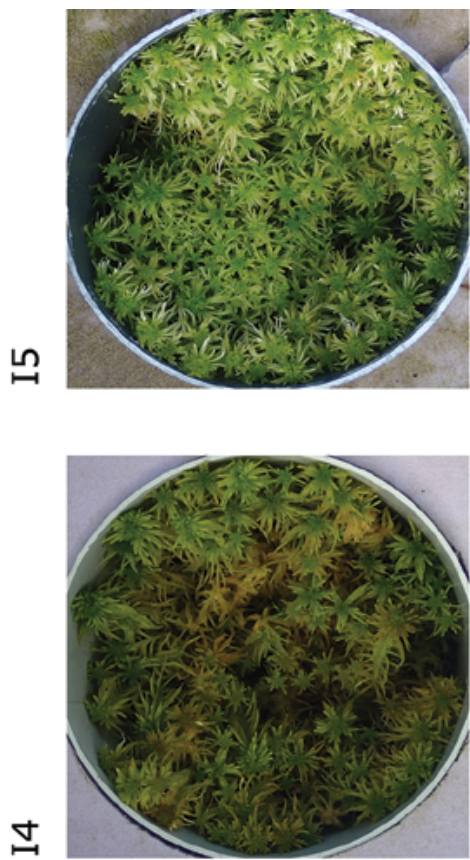

$\stackrel{m}{-}$
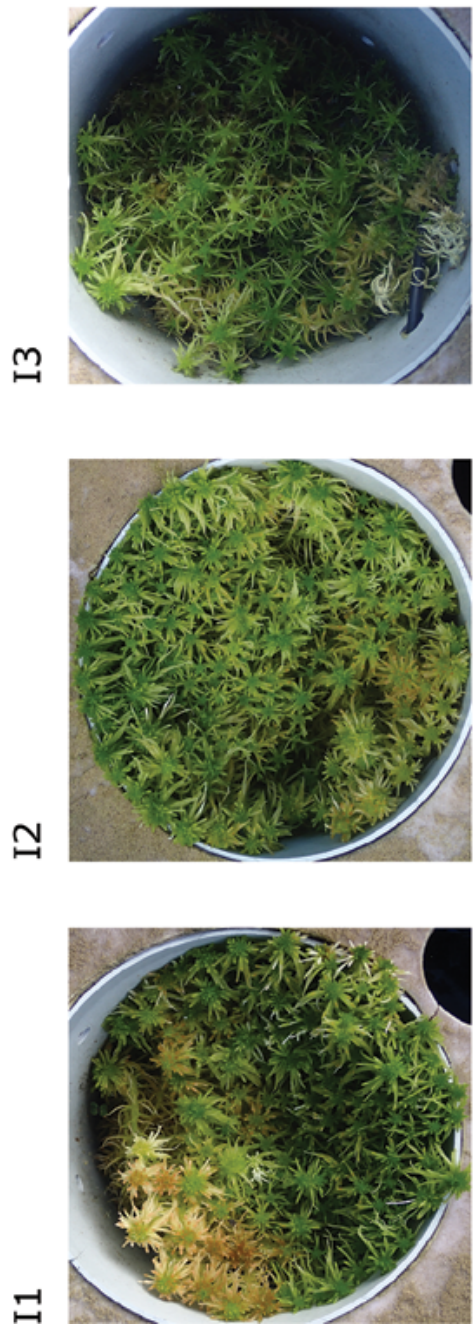

$\stackrel{\Delta}{\Delta}$

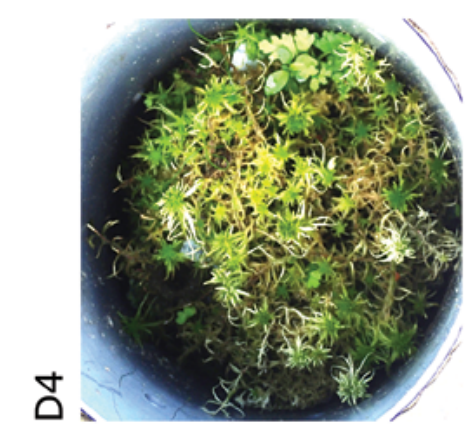

m
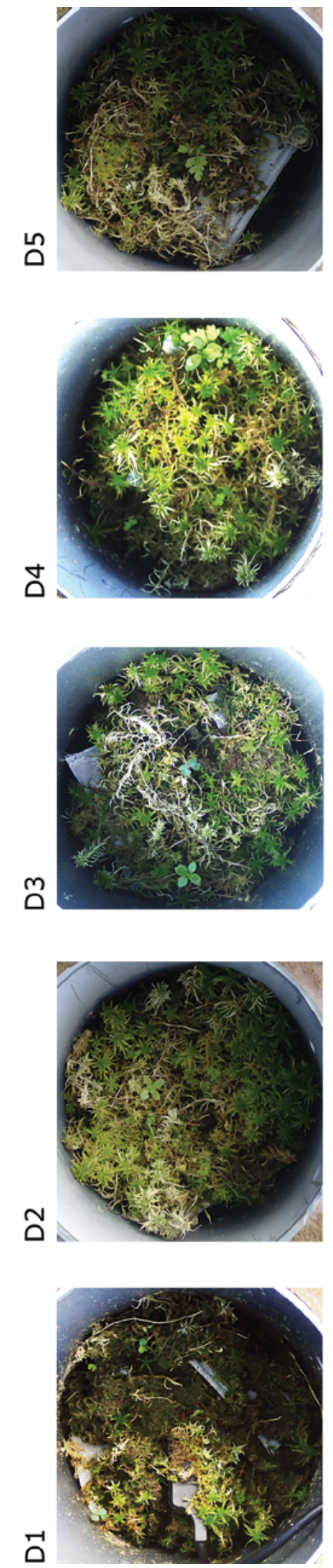

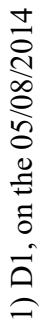


Response of Testate Amoebae to Drainage and Re-wetting 209
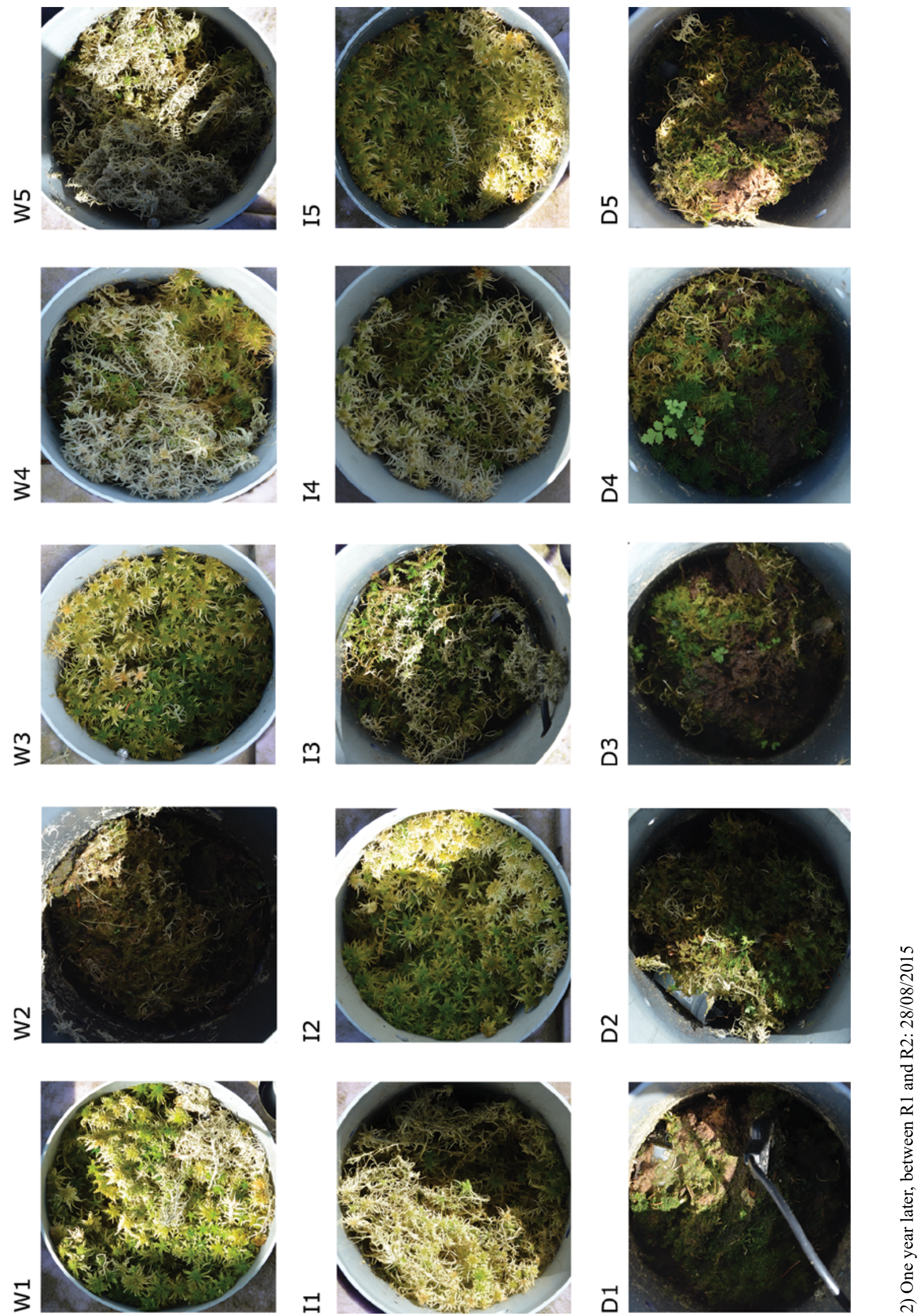
210 I. Koenig et al.
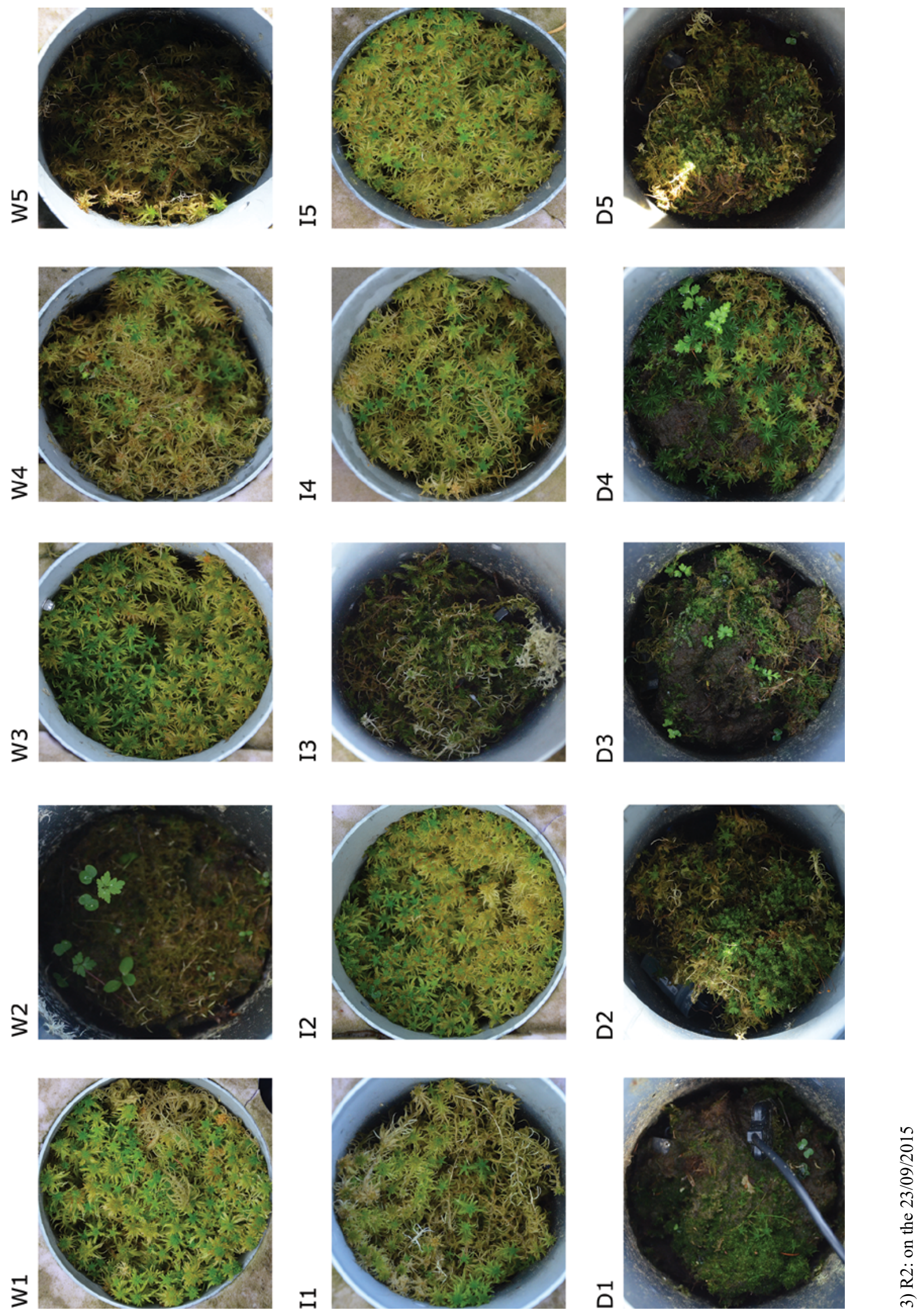